\title{
Militarised violence in the service of state-imposed emergencies over Palestine and Kenya
}

\author{
Annie Pfingst \\ Goldsmiths, University of London
}

\begin{abstract}
Colonial states of emergency are declared and promulgated to contain the disorder of rebellion, resistance and revolt and to effect a return to an order integral to colonial settlement and occupation. The paper draws on colonial archives, analysis of emergency and colonialism evident in the literature, and the contribution of images to guide apprehension of the sites and locations of the emergency landscapes and the geographies of resistance of Kenya from the 1950s and across historic Palestine since 1948. Positing the practices enabled through Emergency regulations as intensified forms of instrumentalised colonial governmentality and violence, part of the structure of settler colonialism, the paper examines the racialised vocabularies of the British colonial administration of the Emergency over Kenya and the Zionist/Israeli state/military frames of Palestinian resistance, the technologies and architectures of subjugation and punishment through which the threat of disorder is contained in carceral zones, and the militarised violence of the colonial response to resistance characterised as catastrophic threat from an enemy located within frames of terrorism, disloyalty and illegality. Photographs taken as part of an inquiry into the architectures, remnants, material assemblages and spatial arrangements found in the emergency landscapes and the geographies of resistance of post-colonial Kenya and across the multiple geographies of historic Palestine are included as evidence of the photographic event and as provocation to thought in an encounter with the workings of colonialism and of resistance.
\end{abstract}

This writing on Emergency applies archival, visual, theoretical and spatial modes of inquiry to historic and contemporary provisions and practices authorised under colonial stateimposed emergencies. It brings forward the rhetoric and events found in archives, the theoretical concerns on emergency and colonialism evident in the literature, and the contribution of images to apprehension of the sites and locations of the emergency landscapes and the geographies of resistance of Kenya from the 1950s and across historic Palestine since 1948. It aims to bring attention to the technologies of oppression authorised through colonial

(C) 2014 Annie Pfingst. This is an Open Access article distributed under the terms of the Creative Commons Attribution 4.0 Unported (CC BY 4.0) License (https://creativecommons.org/licenses/by/4.0/), allowing third parties to copy and redistribute the material in any medium or format and to remix, transform, and build upon the material for any purpose, even commercially, provided the original work is properly cited and states its license. 
state-imposed emergencies and to re-frame the militarised violence through which all that is necessary will be done to protect sovereignty from the resistance of the colonised and occupied and to effect a return to an order integral to colonial settlement and occupation.

In late 2012 at the London High Court, Mau Mau veteran claimants won the right to a full trial hearing of their claims for compensation for alleged torture during the British Emergency in Kenya from 1952 to 1960. Elderly Kenyans sat quietly in the court as the state, through legal argument, attempted to dislodge their claims. ${ }^{1}$ As I observed the legal proceedings in London, Palestinians incarcerated as administrative detainees in Israeli prisons were on hunger strike. The situation reiterated the commonality of the structures of colonialism experienced by Kenyans and Palestinians, in particular those practices enabled through the promulgation of colonial states of Emergency and codified through Emergency regulations.

From the end of the First World War to the late 1960s, Britain introduced martial law and declared states of Emergency against the disorder-ing of state sovereignty by acts of resistance, rebellion and riot across a number of colonies, protectorates and mandated geographies - India, Ireland, Palestine, Kenya, Malaya, Aden. Practices and personnel were moved across the empire - villagisation, mass detention and deportation, for example, were transferred from the administration of the Emergency in Malaya to Kenya. ${ }^{2}$ Palestine and Kenya became linked through technologies of control, containment and punishment as the provisions and practices common to Emergency regulations followed a genealogy from the British Mandate administration to that of Israel over Palestine since 1948, to the Emergency over Kenya in the 1950s. Legal provisions based on racial separation/segregation were applied by Britain in Kenya throughout settlement and continue to be applied by Israel over Palestine. Having detained and deported Arabs during the Arab uprising of the $1930 \mathrm{~s}^{3}$ in the 1940s the British Mandate detained Jewish militants firstly in Eritrea and later at Gilgil in Kenya. ${ }^{4}$ These regulations were followed by the British Emergency (Defence) Regulations,

\footnotetext{
${ }^{1}$ The case was brought by the Mau Mau War Veterans Association together with the Kenyan Human Rights Commission. The defence did acknowledge the claimants had experienced the mistreatment that was the basis of their claims.

${ }^{2}$ Charles Tegart, transferred to Palestine from India, built a line of fortresses along the northern border of Palestine as part of counter-insurgency against the Arab Revolt. See also Khalili, pp. 176-180.

${ }^{3}$ Under the Emergency (Defence) Regulations of 1936 that followed the early Mandate Collective Responsibility Ordinance and Collective Punishment Ordinance (1925); a revised Collective Punishment Ordinance was applied in Kenya in 1930 (Kenya Gazette 20 June, 1930:1520).

${ }^{4}$ Under the Palestine Defence Order in Council of 1937.
} 
1945 which Israel adopted when, on the $21^{\text {st }}$ May 1948, it declared a state of emergency over Palestine, only days after the declaration of the establishment of the Israeli state on the lands, villages and cities lost to Palestinians through the war of 1948, al Nakba. The state of emergency - promulgated for the defence of the state, the maintenance of public order, supplies and essential services (Mahozy 2012, p. 148; Law and Administration Ordinance No. 1 of 5708-1948), and the suppression of mutiny, rebellion, or riot (Adv. Ben Natan et al. 2009) - has been renewed in the Israeli Knesset every year since 1948. In 2012 the Supreme Court rejected a petition first filed in 1999 by the Association for Civil Rights in Israel (ACRI) to cancel the state of emergency in place since 1948 on the grounds that, in part '(Israel) is not a normal country in that its existential threats have yet to be quelled' (ACRI 2012). In October 1952 the colonial office declared an Emergency over Kenya to impose order on the Land and Freedom movement (also known as Mau Mau), a resistance movement framed as lawlessness, violence and disorder (TNA CO/822/443 October 1952). The Emergency in Kenya would last eight years until negotiations brought about a transfer of power and independence. Mau Mau, illegal under Emergency regulations, remained proscribed as a movement and an organisation until 2003 when the Kibaki government lifted the proscription and the case for compensation could begin. Palestine, having been under some form of state of emergency at least since 1937, arguably since 1920 under the Mandate and under Israeli control since 1948, is said to be in a state of 'permanent' (Adalah 2013) or 'perpetual emergency' (al Haq 1989). Colonial sovereignty, suggests Stephen Morton writing on Kenya’s colonial state of emergency, 'was experienced as a permanent state of emergency from the standpoint of the colonised'; the emergency over Kenya signifying the violence and injustice inherent to colonial rule (Morton 2002, p. 112), inherent, one might add, to the 'logic of elimination' that Wolfe (2008 p.102) identifies as central to the settler-colonial project. ${ }^{5}$ Premised as it is on 'the securing - the obtaining and maintaining - of territory' (Wolfe 2008, p.120), settler colonialism frames those features found in common, ${ }^{6}$ both historically in Kenya and across contemporary Palestine including, but not limited to, discursive frames of terra nullius, the

\footnotetext{
${ }^{5}$ Wolfe (2008) distinguishes settler colonialism, determined by this 'logic of elimination' as a primary motivation, from other forms of colonialism that he characterises as chattel slavery (US) or franchise colonialism (India) p.103.

${ }^{6}$ Notwithstanding that the settlement of Palestine started as anti-colonialism began the process of securing independence from colonial rule (Israel-Palestine has been described as 'the only successful settler nationbuilding of the twentieth century’ Elkins and Pederson 2005, p.3) there are innumerable common practices of colonial rule between Kenya and Palestine. See Elkins and Pederson, 2005.
} 
dispossessions and re-territorialisation of what colonialism intended as permanent settlement (Wolfe 2008, p.112), and what Elkins describes as 'settler tyranny'.

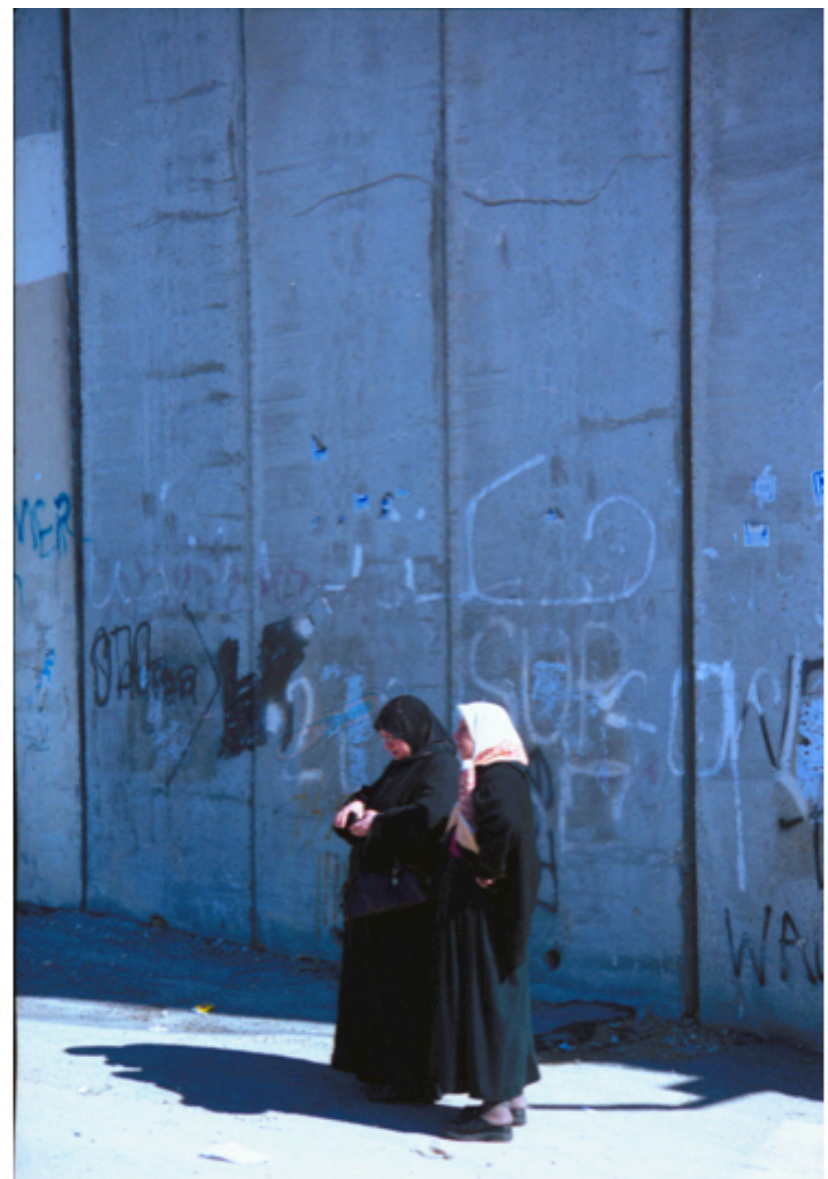

Figure 1. The Wall, Abu Dis, Palestine 2007. Photo: Annie Pfingst

This writing is accompanied by photographs taken as part of my inquiry into the architectures, remnants, material assemblages and spatial arrangements found in the emergency landscapes and the geographies of resistance of post-colonial Kenya and across the multiple geographies of historic Palestine. Taken as I walked, was guided, stopped to observe, they are inscribed here as encounters to work together with the material gathered from the archives, from Kenyan and Palestinian writings, and from discursive analysis in an apprehension of the work of emergency. Images are offered here not as forensic evidence but as evidence of the photographic event or the event that photography has encountered (Azoulay 2012, pp.11-27) and as provocation to thought, an opportunity to “"slow down” reasoning' as Stengers posits, 'to arouse a slightly different awareness of the problems and situations mobilizing us'

\footnotetext{
${ }^{7}$ Caroline Elkins argues that 'settler tyranny - with its vicious racism, restrictive conceptualization of citizenship, and infiltration into the colonial state - unleashed uncontrollable violence in the final moments of empire, (2005b, p. 219). Settlers in Kenya were an integral part of the Emergency regime; settlers in the Occupied Palestinian Territories are part of the civilian and military regime of Occupation.
} 
(Stengers 2005. p. 1). As an encounter with the workings of colonialism and of resistance, this is also the moment to contemplate the 'civil contract of photography' in which the ethics of viewing shifts to the 'spectator's responsibility toward what is visible' (Azoulay 2008, p.131; Pfingst \& Rosengarten 2012, pp.102-5). Butler reminds us that apprehension is a process of framing through which some lives are recognisable as life whilst others do not register as grievable, do not command our recognition of their deaths and thus not of their lives (2008, pp. 2-15). This essay considers the conditions of state-imposed emergencies through which categories of life not apprehended as grievable, are not protected but rather framed as threats not only to order but to the 'foundational fictions' (Stoler 2002, p. 99) of colonial regimes rendering them subject to the extremes of colonial emergency practices of control, containment and punishment.

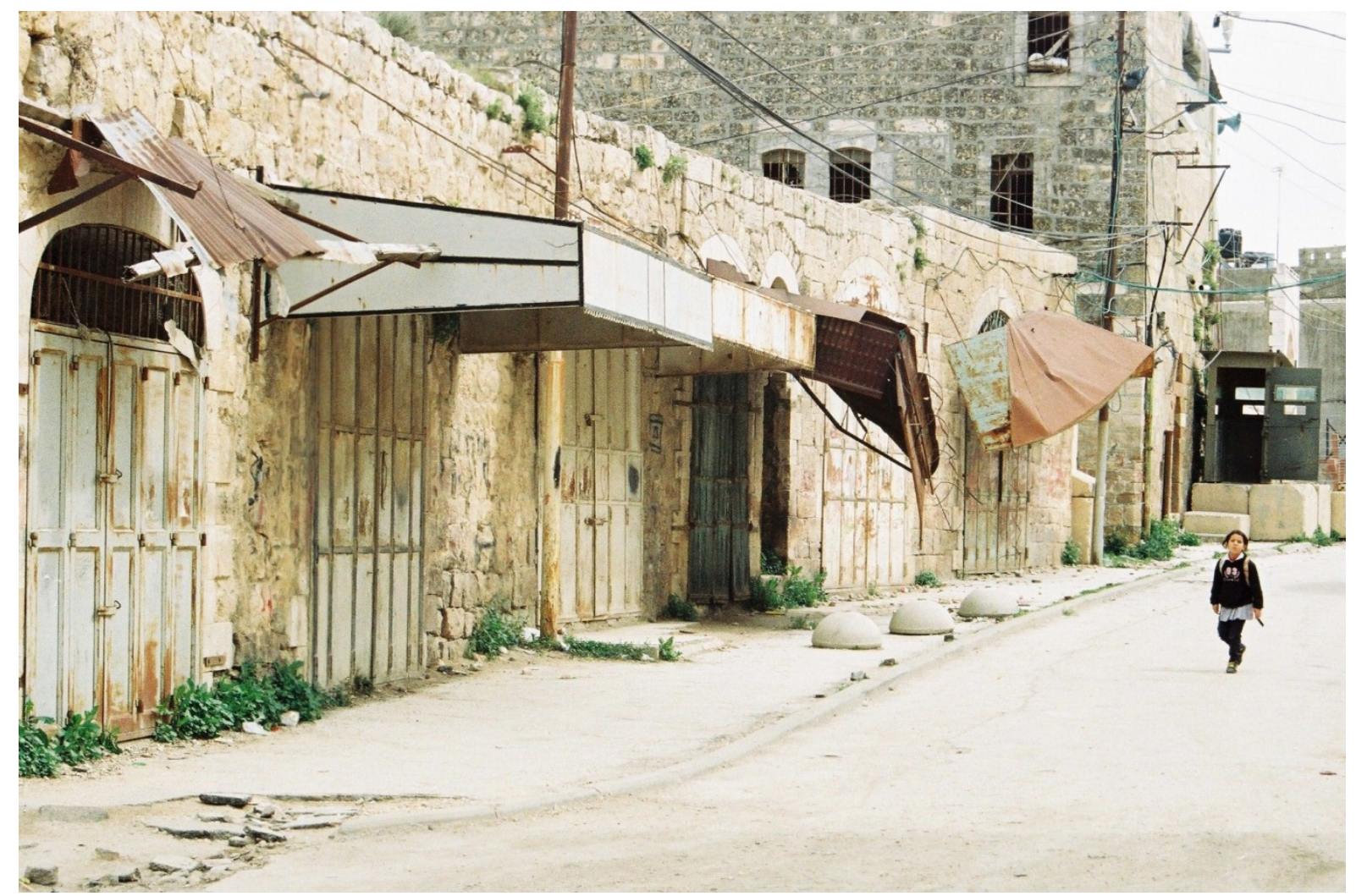

Figure 2. Hebron, Palestine 2014.

Photo: Annie Pfingst

The declaration of an Emergency and the practices enabled through Emergency regulations are intensified forms of instrumentalised colonial governmentality and violence, part of the structure of settler colonialism (Wolfe 2006, p. 388) - of settlement, dispossession, repression, expulsion and containment - in which the technologies and architectures of oppression are codified and the legitimacy of colonialism unquestioned by either the colonial administration or the settlement project. The state of emergency as an oppressive regime is 
characterised by surveillance, arrest and detention, screening, secret evidence and torture, and the workings of secret services and militarised violence - characteristics evident in Israeli daily practices over Palestine to structure what Pappe describes as an oppressive state - a mukhabarat state - a secret services state (2008, pp.148-169). Three forms of violence, according to Mbembe - founding violence, the violence of legitimation that in turn produced 'an imaginary capacity converting the founding violence into authorizing authority' and a third form of violence that would ensure the 'maintenance, spread and permanence' of the authorizing authority - form the seamless web of colonial sovereignty (2001, pp. 24-25). This writing departs from Agamben's analysis of the occurrence of sovereign violence outside the law as necessarily delineating the state of exception and draws instead on the codification of laws, territorial distinctions and the structures and political logic of colonial governmentality provided by what Mbembe sets out as commandement, that is a 'regime d'exception' (Kohn 2011, p. 94) - '(t)he lack of justice of the means, and the lack of the legitimacy of the ends, conspired to allow an arbitrariness and intrinsic unconditionality that may be said to have been the distinctive features of colonial sovereignty' (Mbembe 2001, p. 26) . Turning our gaze away from colonialism's legitimating rhetoric we come to what Kohn suggests is evident in the work of Kenyan writer Ngugi wa Thiong'o - an examination of what 'emergency tells us of the legitimacy of colonialism itself' (2011, p. 80).

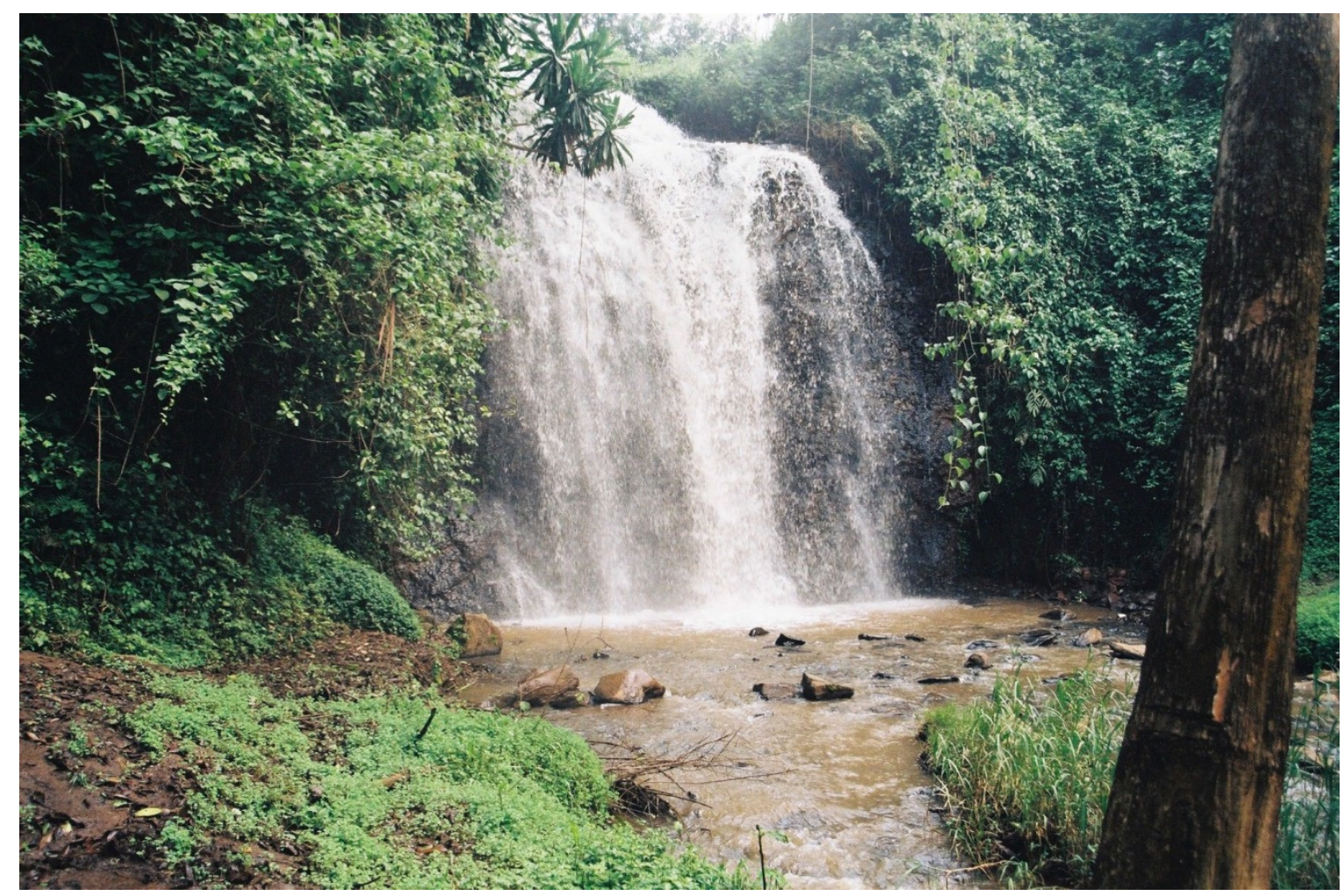

Figure 3. Mau Mau cave Kahuru River, Thigingi, Nyeri District, Kenya 2013. Photo: Annie Pfingst 
For Palestine, the colonial antecedents found within the 'war to end all wars' invoked the British Mandate and the Balfour Declaration. Martial law promulgated under the British Mandate over Palestine introduced collective punishment, the construction of guard posts and security fences against infiltration, provided for swift prison sentences, mistreatment in interrogation, death sentences and executions by hanging, administrative detention without trial, curfew and curfew orders dropped from airplanes, searches, punitive demolitions, and private armies (Segev, 2000). For Kenya the 1919 soldier settlement scheme that came out of the 'war to end all wars' was seamlessly added to the colonial settlement project.

An array of state-imposed Emergency practices and determinations evident in the British colonial Emergency over Kenya in the 1950s and by Israel over Palestine since 1948 administer detention without trial using secret evidence; enact land forfeiture and demolition; impose curfew and close or prohibit entry to designated and mapped locations; monitor, restrict and control movement through a system of passes and permits and forms of permission; construct trenches, fences, walls and blockades; invoke questions of loyalty and of sedition; provide for collective punishment, deportations, expulsions, removals and exile; authorize mass arrest, arrest without charge, punitive conditions of detention; screen, interrogate and torture; photograph, fingerprint, map and colour code geographies and detainees; determine, measure and ration the allocation of food; enable capital punishment and executions through targeted assassination; enclose and concentrate populations; authorise military operations and aerial bombing; destroy material culture and ban cultural practices and national modes of identity; and construct affiliations of loyalty that are messy, unpredictable and in constant flux. 


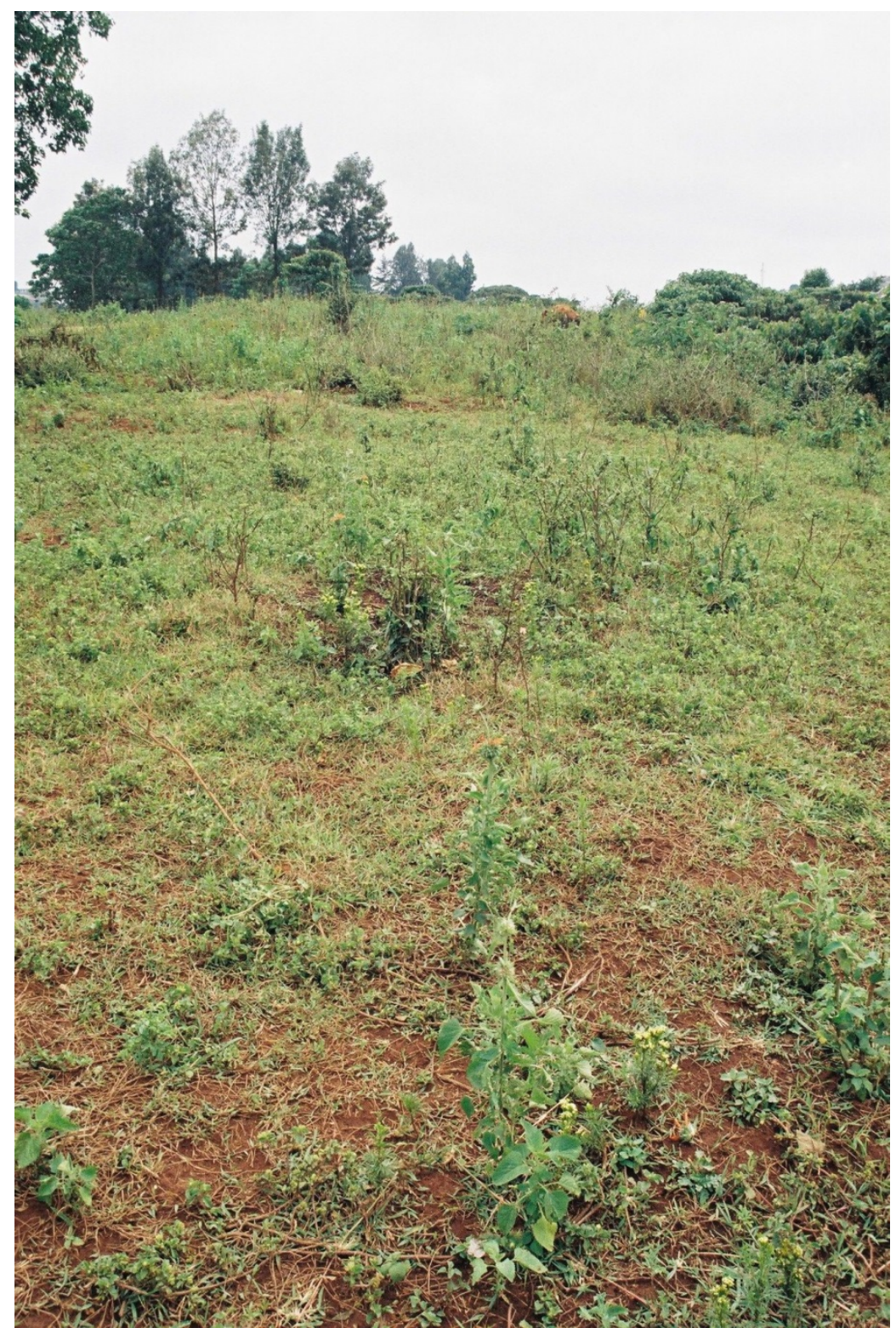

Figure 4: Site of mass grave, Kiawara, Nyeri, Kenya 2013.

Photo: Annie Pfingst

Walking down the path on the edge of Kiawara outside Nyeri in the highlands of Kenya, I cross the open drains and climb up the hill opposite. I walk slowly beside my guides across the site of a mass grave. Mounds in the earth indicate the trenches in which the British colonial administration buried some three hundred bodies during the Emergency against the Mau Mau rebellion in the 1950s. I turn 360 degrees to apprehend the remnants of an emergency landscape intertwined with multiple geographies of resistance and overlapped by the geography of a post-colonial Kenya. What do we apprehend, recognise as living in this encounter with a remnant, a landscape, when we look across or dig down into the vertical strata of the land; or walk between the buildings in a boys rehabilitation school that was once a detention camp; or along the deep ditches that are all that is left of the trenches; the grid 
arrangement of houses and shambas that mirrors the straight lines of a concentrated village; or down the steep path through the forest, across rocks and a river to find ourselves at the mouth of a cave used by Mau Mau for shelter and gathering?

I remember walking past two women standing, talking on the Jerusalem side of the Apartheid Wall - small figures against the immense grey concrete structure reaching metres above their heads. Abu Dis. It was a still moment in this landscape of separation, enclosure and control. Farther behind us an old man walked slowly along the road. Earlier a military vehicle had sped along the military road that is an integral part of the construction of the Wall. How do we apprehend the lines of people waiting, the concrete holding sheds, the electronic monitoring, the glassed in soldiers booth, the guns, military vehicles and radios of the checkpoint; the concrete panels, the round towers of the Wall topped by barbed wire; the surveillance cameras dotted throughout the old city of Jerusalem, the soldiers; the wide swathe of a settlement lying across the Judean Hills seen from the road between Beit Sahur and Ramallah; a Palestinian town glimpsed in the valley? How might we apprehend the miles on miles of fences that guard the military installations and zones across the southern Naqab/Negev?

This inquiry works at the intersection of the knowledges held in Kenyan and Palestinian writings and collections, images, both historic and current, including photographs made by the author through this inquiry on Emergency, and the archives of colonial files and documents encountered as 'sites of contested knowledges' (Hamilton et al., 2002, p.15). Apprehension of the secret letters, orders, directives, opinions, photographs, lists, intelligence and security reports, legal deliberations and juridical decisions contained in the British colonial 'migrated files ${ }^{8}$ provoke a particular set of considerations. Colonial framing of the colonial enterprise is administrative, privileged and dominant in official and imperial discourse. ${ }^{9}$ The files frame beginnings to rebellion, riot, or resistance as phenomena that explode into the colonial space as if from somewhere outside. There is no 'before, ${ }^{10}$

\footnotetext{
${ }^{8}$ Boxes of files on the late British colonial administration across 37 colonies were found and released to the National Archives as a result of the Mau Mau case at the High Court in London. They are tagged as the 'migrated files'.

${ }^{9}$ See Ranajit Guha, 1988, 'The Prose of Counter-Insurgency’ .

${ }^{10}$ From the archival records it is clear that the precursors to emergency practices existed within the structures of the British colonial project in Kenya - from the expropriation of land to the Kipande system, from identity cards to passbooks and movement permits, from squatter lines to the concentrated villages - Registration of Natives Ordinance (1921); Masters and Servants Ordinance (1906); Native Administration Ordinances, Outlying Districts Ordinance (1902); the Special Districts Administration Ordinance (1934).
} 
deliberations are only ever interpretations of intent or colonial imagining according to colonial configurations and discourses of power (Hamilton 2002, p. 9; Guha 1988) resulting in a linear narration that elides 'traces of marginal lives' (Hamilton et al. (ed.) 2002, p.12). Traces of marginal lives appear as names in the lists of the administration of detention and capital and collective punishment, or in propaganda flyers for capture, or in the correspondence between those seeking permission to enter or leave closed zones or seeking redress for harm under detention and the administrators of the colonial emergency; lives framed within colonial governmentality. In composing truth/fact, the archive, whose existence Mbembe posits 'constitutes a constant threat to the state' (2002, p.23) assembles time, places fragments of life in order, and formulates a coherent story of beginnings and ends to create 'an illusion of totality and continuity' (2002, p.21) in effect constructing what Stoler describes as colonialism's 'moral narration' (2002, p.90). The files from the administration of the Emergency against Mau Mau reveal that those resisting colonial rule were considered law breakers, political agitators, terrorists at large, rebels, bad persons, prominent gangsters, agitators, enemy actors, 'leaders of violent resistance against the forces of law and order’ engaged in ‘acts of rebellion’ (TNA FCO 141/6809 1956). ${ }^{11}$

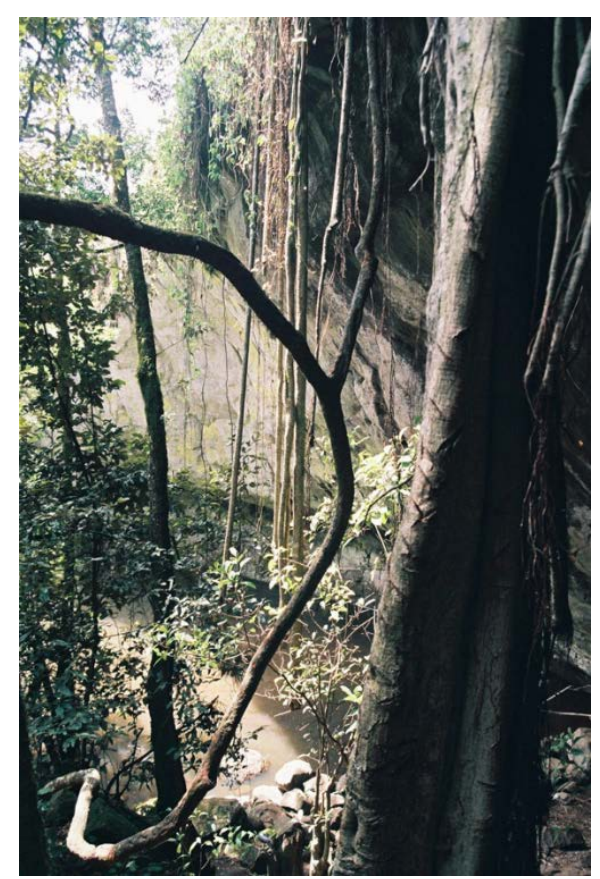

Figure 5. Mau Mau shelter, Mount Kenya 2013. Photo: Annie Pfingst

\footnotetext{
${ }^{11}$ In The Prose of Counterinsurgency, Ranajit Guha analyses the language of colonial reports on India to note : 'they make the despatch into more than a mere register of happenings ... an interpretation so that the protagonists emerge from it not as peasants but as 'Insurgents', not as Musalman but as 'fanatic'; their action not as resistance ... but as 'the most daring and 'Wanton atrocities on the inhabitants'; their project not as a revolt ... but as 'defying the authority of the State', not as a search for an alternative order ... but as 'disturbing public tranquil(l)lity''(p. 57) emphasis in original.
} 
Intended to be at least secret and hidden if not destroyed, the files on Kenya did in effect 'testify that a life did exist, that deeds were enacted, and struggles engaged in or evaded' (Mbembe 2002, p. 22) as the High Court in London judged that the case could go to a full trial asserting the rights of the claimants on the basis of the material available to the court including from the recently released files. A year later the British Government agreed an out of court compensation settlement. ${ }^{12}$

In the second half of this essay, I examine the racialised vocabularies found in the British colonial administration of the Emergency over Kenya and the Zionist/Israeli state/military frames of Palestinian resistance, the technologies and architectures of subjugation and punishment through which the threats of disorder are contained in carceral zones, and the military violence of the colonial response to resistance characterised as catastrophic threat from an enemy located within frames of terrorism, disloyalty and illegality.

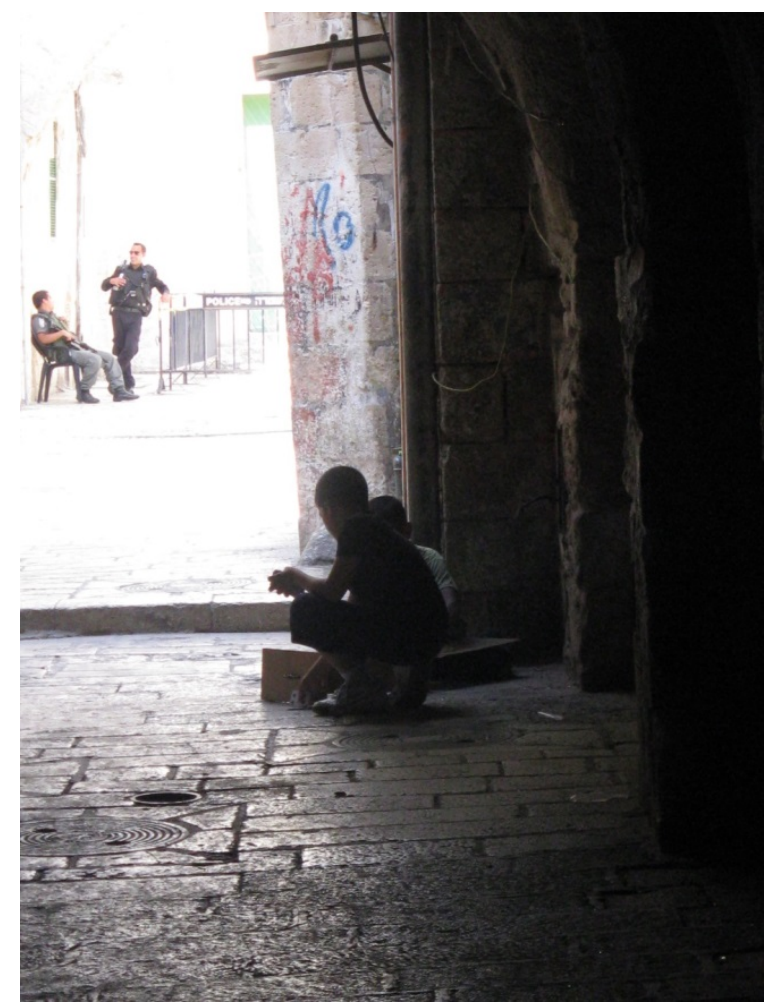

Figure 6. Old City, Jerusalem, Palestine 2011. Photo: Annie Pfingst

\footnotetext{
${ }^{12}$ It recognized that the claimants had been 'subject to torture and other acts of ill treatment at the hands of the colonial administration’ (Statement to Parliament on settlement of Mau Mau claims, 2013) but denied liability for 'events that occurred overseas outside direct British jurisdiction more than fifty years ago' suggesting that they could not 'be resolved satisfactorily through the courts without the testimony of key witnesses that is no longer available', https://www.gov.uk/government/news/statement-to-parliament-on-settlement-of-mau-mauclaims, last accessed 10 December 2014
} 
The spatialisation effected through settlement and occupation produces a racialised geography in which the sovereign claim to power determines who can live and who must die. Absolute rule over the bodies of the enemy, suggests Mbembe, is authorized through the 'racial denial of any common bond between the conqueror and the native' (2003, p. 24), the enemy, the savage, the terrorist. Racialised designations, locating the body of resistance outside the norms of what constitutes the human, authorise levels and forms of violence against resistant bodies and geographies and render those resisting colonial 'technologies of rule' (Stoler 2002, p. 90) as the agents of impending catastrophe and destruction. Palestinian resistance is always and only understood to pose an existential threat and all Palestinians, including children, are construed and constructed as terrorists whose intention is the catastrophic annihilation of the state. Accused of placing their children and civilians as human shields in times of conflict, Palestinians are instrumentalised as arsenals and weapons of war, as the enemy, as infiltrators, as snakes (Electronic Intifada 7 July 2014). This authorising discourse was already set in motion when the Mandatory response to the Palestinian revolt of the 1920s-30s included execution by hanging, the collective punishment of villages, and torture.

The British regarded Mau Mau practices, such as the taking and administration of oaths, as bestial. Whipping was imposed for hardened, violent or bestial criminals in order to 'break down a criminal arrogance and disregard of all decent principles’ (TNA FCO141/6145 1954). The Kenya Weekly, reporting on the deaths of 11 detainees in Hola Detention Camp, commented on the 'appallingly difficult task of redeeming tens of thousands of men from bestiality to decency’ (Kenya Weekly 31 July 1959 in TNA FCO141/5655). They are, in Butler's terms, not grievable, and therefore their suffering is not apprehended as suffering (2009). The bodies of resistance are apprehended only by what they refuse - the authority and legitimacy of the rule of colonial occupation and settlement. Screening, the process to 'extract confession by intensive interrogation' (TNA FCO141/6521 1954-58) was intended to 'cleans(ed) the hearts and minds of all those contaminated by the Mau Mau' so they would ‘regain the old spirit of loyalty between master and man’ (TNA 1953 FCO141/6750).

Settlement is in any case never over because it always provokes what Farred calls the 'issue of origin', the potential disturbance that emanates from the past. The possibility of violence always remains as a consequence of the force of the 'unsettlement required to produce settlement' (Farred 2008, p. 799). The Palestinian assertion of self-determination further 
animates collective punishment and punitive measures of containment including mass arrests and curfews across the occupied West Bank and East Jerusalem and the siege/blockade and aerial bombardment of Gaza.

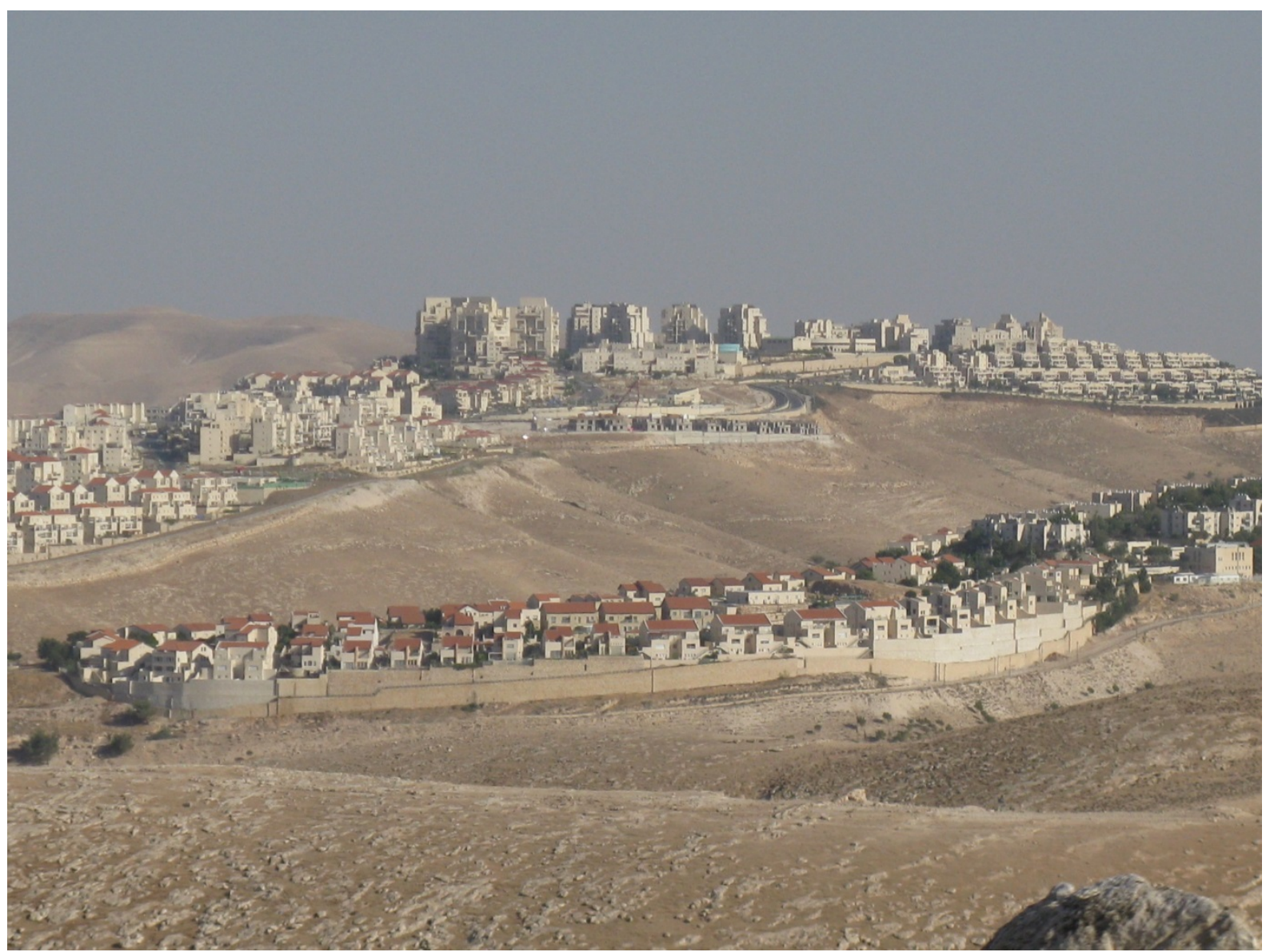

Figure 7. Settlement between Beit Sahur and Ramallah, Palestine 2011.

Photo: Annie Pfingst

Resistance and rebellion to the very conditions - loss of life, loss of land, loss of freedom - of colonial oppression and dispossession are met by colonial emergency technologies and architectures of subjugation and punishment through which the threat of disorder is contained in carceral zones across settlement and occupation geographies, zones in which Emergency practices monitor, prohibit, detain and deport. Some 150,000 Kenyans were detained in the years of the Emergency from 1952-1960 (Anderson 2005, p. 5); by 1954, Governors Detention Orders were extended to the detention of all those suspected of being or potentially being trouble-makers in order to 'demonstrate that Mau Mau was not to be tolerated (TNA CAB/129/65 Telegram No 72, 27 January 1954). Some would be detained 'on grounds of public security because of ... complicity in Mau Mau' (TNA FCO141/6298 1956), to having taken the oath even where no charges were brought. The complex Kafkaesque nature of the 
detention regime and of screening classified detainees as Z1, Z2 or Y, then later as Mau Mau leaders, self-confessed murderers, surrenderers and ex-convicts, minor Mau Mau adherents, and as co-operative or anti-government (TNA FCO141/6298 1956). The conditions in the detention camps, spread across the geography of Kenya were harsh, accompanied by forced labour and violent interrogation. Detainees were allocated to camps on the basis of the severity of their offence and moved through what was known as the pipeline - a series of detention and works camps - on an assessment of their willingness and capacity to give up Mau Mau, to give up the oath, to show loyalty to the colonial crown, to be 'rehabilitated' that is to be redeemed or cleansed so that a 'contiminated (sic) person may once again be accepted by his people as clear and ready to assist the Government if called upon to do so.' (TNA FCO 141/6521 1954-58). The most resistant Kenyans held in the detention camps were designated 'irreconcilable' for their refusal to recant their affiliation with Mau Mau, to show loyalty or to reconcile themselves to the authority of colonial power and control. Only then would they be considered ready to transit through the rehabilitation structures of the pipeline and on to eventual release. As 'irreconcilables', they were sent to the exile camps on the islands of Saiyusi and Mageta on Lake Victoria. Their resistance and refusal turned them into criminals who would face the most severe punishment. Between October 1952 on the declaration of the Emergency and March 1957, 1071 Kenyans were executed for offences under Emergency Regulations - including murder; furthering terrorism; demanding supplies; consorting; and offences relating to oaths. It became an offence punishable by death to 'do, attempt, or conspire to do any act likely to endanger life, assist terrorists or impede the operations of the security forces' (TNA FCO822/728 Press Office Handout No 139 1953). 


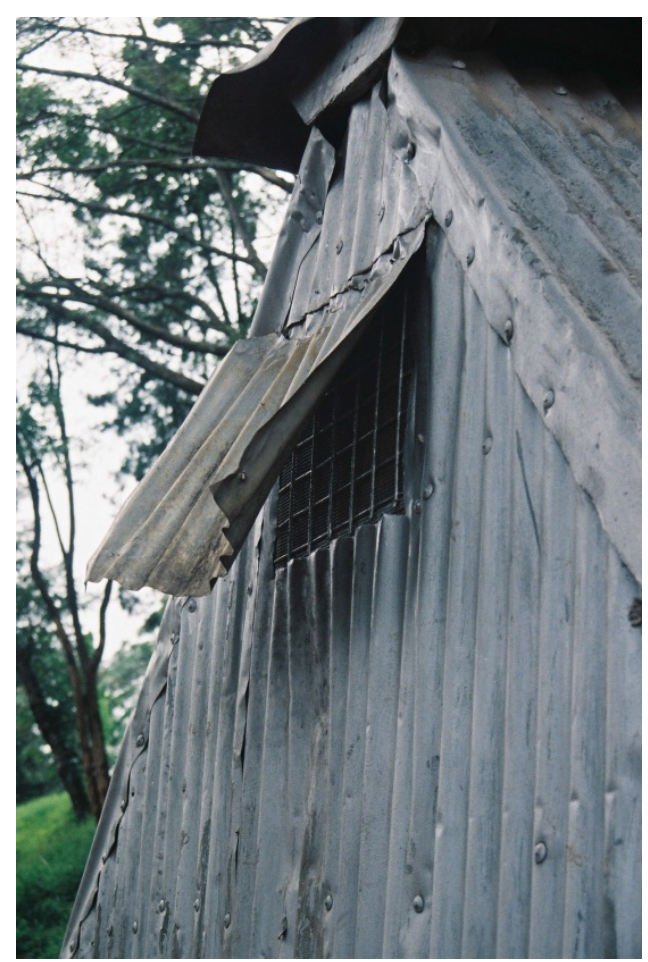

Figure 8. Remnant detention camp, Mweru, Nyeri county, Kenya May 2013. Photo: Annie Pfingst

Through curfews and prohibited or closed areas, the colonial administration of emergency contains threats of disorder and punishes resistance as it authorises or withholds permission to enter or leave locations mapped and gazetted as closed or prohibited. During the Emergency over Kenya, access to geographies classified as 'prohibited’ or villages and rural areas as 'closed' was prohibited except to the few who could secure permissive passes through a complicated process of application and approval, and then only for those known to be loyal to the colonial forces and with good cause to be entering a prohibited area (TNA CO822/451 1952-3)). Hundreds of barriers - including military checkpoints, trenches, agricultural gates - impede and restrict Palestinians in the occupied West Bank and East Jerusalem whose movement is dependent on residency or enabled with permits and ID cards - Jerusalem ID, West Bank ID, Gaza ID, citizen of Israel, permit to enter for medical reasons, permission to enter for work; a colour coded - blue, green, orange - permit system of surveillance, monitoring and control (Tawil-Souri 2011, p.67). Palestinians are prohibited from entering vast areas designated as military zones and all movement between the two geographies of the Occupied Palestinian Territories - between the West Bank and the Gaza Strip - is closed except through deportation. Thirty-two Palestinians have been deported from the West Bank to Gaza under the Israeli policy of 'assigned residence' since 2002 (B'Tselem 2014). Deportations from the Gaza Strip and the West Bank between 1967 and 1978 - for incitement or for security, for choosing 'migration' over prison sentences - were authorised 
under the provisions of the British Mandatory Emergency (Defence) Regulations 1945 (Lesch 1979, p.101).

Colonial emergency regimes manage surveillance, monitoring and punishment through the architectures of concentration and the spatial technologies of closure. The emergency in Kenya forcibly removed people through the policy of villagisation from their scattered homesteads on the hills of the central highlands into concentrated villages as purportedly protective, but in effect punitive measures where they could be closely monitored; their existing huts were burnt. In the Nyeri District, by the beginning of 1955, 165 villages housed $75 \%$ of the population and across the Central Province, 600,000 people had been moved and 155,000 huts destroyed (KNA OP/E/1/982 1955). The conditions and brutality of forced labour, curfew, punishment and little food (women were allowed out for one hour a day to gather food) exposed the women, their children and the older men in the concentrated villages to extremes of injury and disease, violence and death (Elkins 2005). Severe outbreaks of disease such as typhoid were recorded in the detention camps, including for example at Manyani (TNA CO822/801 1956).

Palestinian refugees from the war of 1948 are contained in nineteen refugee camps in the Occupied Palestinian Territories - among them Balata, Kalandia, Aqabat Jaber, Aida, Jenin, Shu'fat, al Jalazone - enclosed within the occupied West Bank and East Jerusalem by the Wall and in Gaza - Rafah, Deir al Balah, Khan Yunis - by the siege. As well as demarcating zones of closure, the Wall, purportedly constructed as a temporary security measure, punishes Palestinians through enforced and restricted movement and appropriates land into the Israeli settlement project as its construction makes its way along the eastern side the length of the Green Line. Even before the military attack of July 2014 the seven yearlong siege of Gaza produced conditions where the maintenance of life itself is compromised in the extreme. Controlling the capacity for life, also through carefully controlled abandonment (Azoulay/Ophir 2012, pp.178-199) produces conditions in which the maintenance of life is restricted and curtailed - the production of extreme precarity threatens, at the same time as it ‘indefinitely suspends’, catastrophic (humanitarian) emergency (see Azoulay/Ophir 2012, p. 195). 


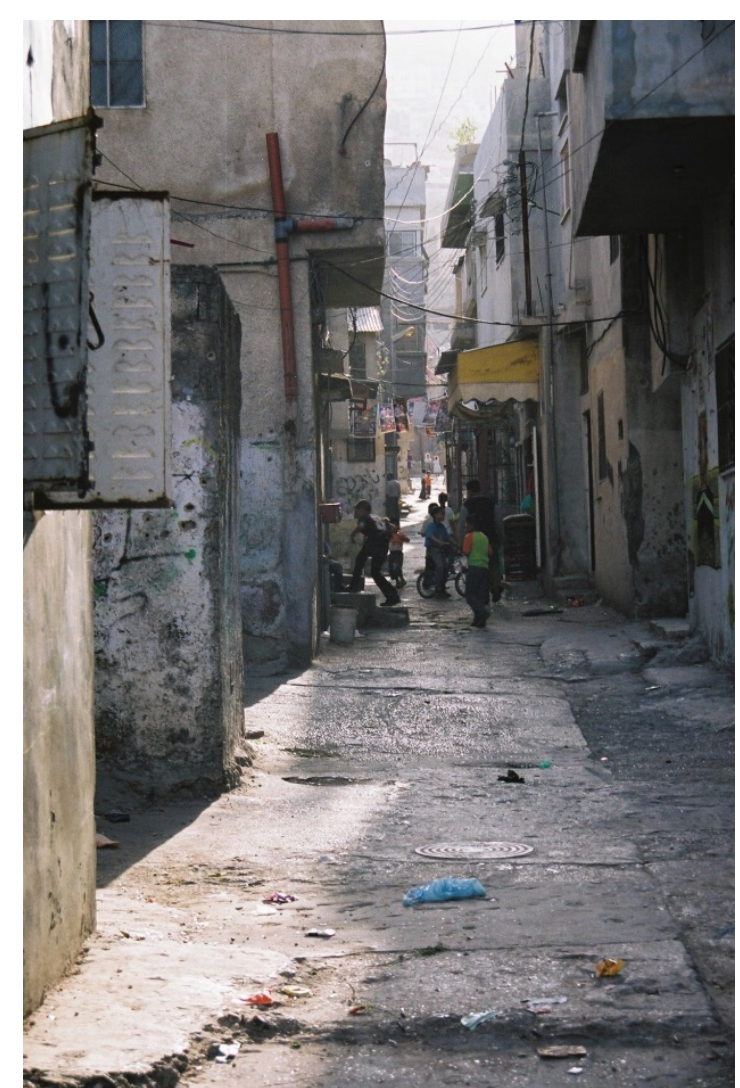

Figure 9. Balata refugee camp, Nablus, Palestine 2007. Photo: Annie Pfingst

Colonial emergency structures and practices, enacted across geographies that had already produced new cartographies of borders and boundaries through the colonial 'division of space' and the 'writing of new spatial relations' (Mbembe 2003, pp.25-6) engender destruction, separation, enclosure, restriction, containment and fragmentation. ${ }^{13}$ The British Mandate over Palestine introduced land mapping, registration and appropriation; laws on citizenship and collective and individual rights; mapped state borders and movement; and constructed settlement practices and militarized landscapes of control. The assemblage of Israel over Palestine is always in flux, continuing to locate Palestinians within multiple spaces of dispossession and oppression, imprisonment and separation continually remade, constantly assembling spatial arrangements across fluid zones of militarized control.

Spatial disintegration and fragmentation, themselves technologies of control and domination (Ophir 2009), assemble landscapes of emergency and re-assemble multiple geographies of resistance. Every location becomes the site for the confrontation between the agency of

\footnotetext{
${ }^{13}$ Mbembe suggests that coming as it did at the end of the European colonial period and at the beginning of decolonization, the late modern colonial occupation of the Palestinian territories, combines the disciplinary, the biopolitical and the necropolitical manifesting in territorial fragmentation, a splintering occupation, and infrastructural warfare (2003, pp. 27-30).
} 
resistance and the agents of sovereign power and control. Every location becomes a frontier; every confrontation between an occupying force and those colonized occurs in the zone of emergency. A deep trench filled with spikes surrounded Mt Kenya; they were placed around the concentrated villages to control and contain the population and to isolate Mau Mau fighters and restrict their access to food. The Wall fragments the geography of the occupied West Bank and East Jerusalem leaving in its wake the debris of construction: demolished houses and villages; uprooted orchards and olive trees; broken wells and farm buildings, stonewalls and terraces. Since 1948, swathes of Palestinian property have been demolished and rendered uninhabitable through military exercises including in Gaza. Military incursions - in Jenin and Nablus as part of the 2002 Operation Defensive Shield - reshape the fabric of Palestinian urban space, including that of refugee camps. Some 27,000 Palestinian structures have been demolished in the Occupied Palestinian Territory (including East Jerusalem) since 1967 some through military destruction (47\% between 1967 and 2012), some under Civil/Administrative Authority, and some as punitive measures (ICAHD 2014). The demolition of Bedouin structures is a daily occurrence across East Jerusalem, the Naqab and throughout the Jordan Valley. During the 2014 Israeli aerial bombing and land offensive across the Gaza Strip, more than 16,700 housing units were destroyed or severely damaged (UNOCHA oPt 12 August 2014). In order to control and limit movement and deny access to food and supplies, colonial emergency practices delineate zones of exclusion across which it is forbidden to pass and in which growing crops was prohibited. In Kenya, a zone was demarcated between the fields and Mt Kenya and the growing of maize and potatoes prohibited. Israel delineated a military buffer zone inside the Gaza border - the most fertile of Gaza’s land no longer available for cultivation. 


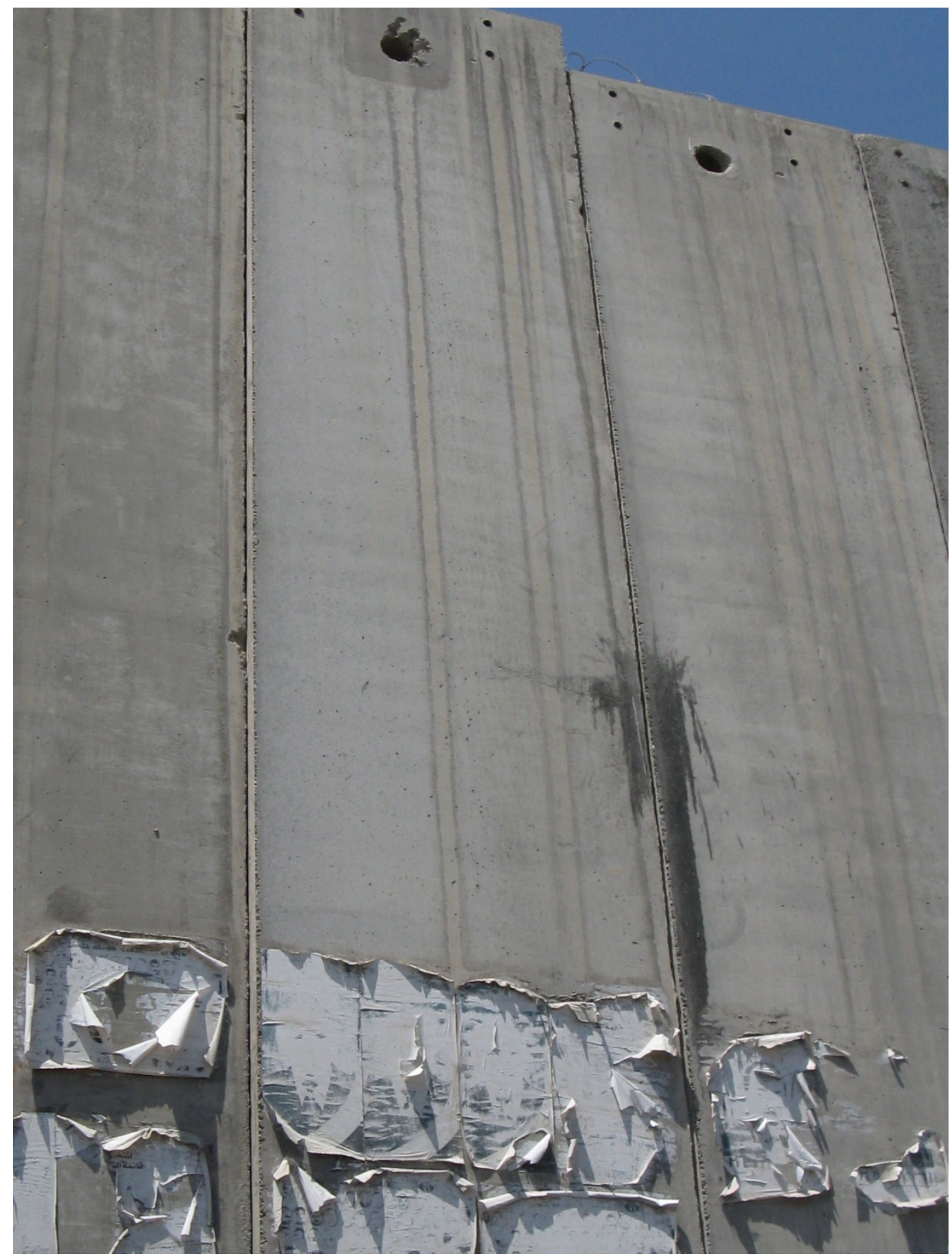

Figure 10. The Wall, Palestine 2011.

Photo: Annie Pfingst

The total closure effected through siege acts as both collective punishment authorised through a state of emergency and a military institution in which the entire population becomes the target of the sovereign (Mbembe 2003, p. 30). The practices of states of emergency - aerial mapping and bombing of enemy locations, the deployment of army and military personnel, the drawing up of military manoeuvres, the application of the hardware of war - are shaped by the logic and authorised by the presumption of defence that in turn enables military practices to treat acts of resistance as acts of war and those resisting as combatants. The story 
of the emergency in Palestine and specifically in Gaza, does not begin with the killing by burning of Palestinian Mohammed Abu Khudair in early July 2014 in the Jerusalem forest in revenge for the abduction and killing of three Israeli settler teenagers from the settlement of Kfar Etzion, north of Hebron, nor with the arrest of some 700 Palestinian men and boys across the occupied West Bank as Israel searched for the settler teenagers. Nor even with the sniper shooting of Nadim Siam Abu Nuwara and Mohammed Mahmoud Odeh Salameh at an annual Nakba Day protest outside Ofer prison in the occupied West Bank (Mondoweiss May 20 2014). Nor does this story begin with the July-August 2014 Israeli Operation Protective Edge that killed and injured thousands of Palestinian civilians across Gaza through military missile air attack and the tanks of a ground offensive. There are here no originary acts to a cycle of killing.

If there can be said to be a beginning, it is with the colonial settlement and occupation of Palestine and the Israeli declaration of a state of emergency in May 1948 outlined above. A complex, layered set of mechanisms and procedures of the state of emergency shape Israeli governmentality both inside the state and across the Occupied Territory. A system of mandatory, administrative and primary emergency laws, together with belligerent occupation, construct a fluid and enduring system, enabling shifts and turns to developing situations, always maintaining a semblance of legality to veil its political intentions and always maintaining a state of emergency to authorize laws and legal orders (Mahozy 2012). The state of emergency structures not only the military occupation of the Palestinian territories, but the matrix of the legal, the civil, the commercial and the political. Inhabiting a geography designated by Israel as an enemy entity, the people of Gaza, 80\% of whom are refugees from the expulsions from Southern Israel in 1948, are simultaneously inside and outside political space. Participation in 'hostile acts against the State of Israel' renders Gazans illegal combatants subject to the provisions of the Incarceration of Unlawful Combatants Law (Hamoked 2002). 


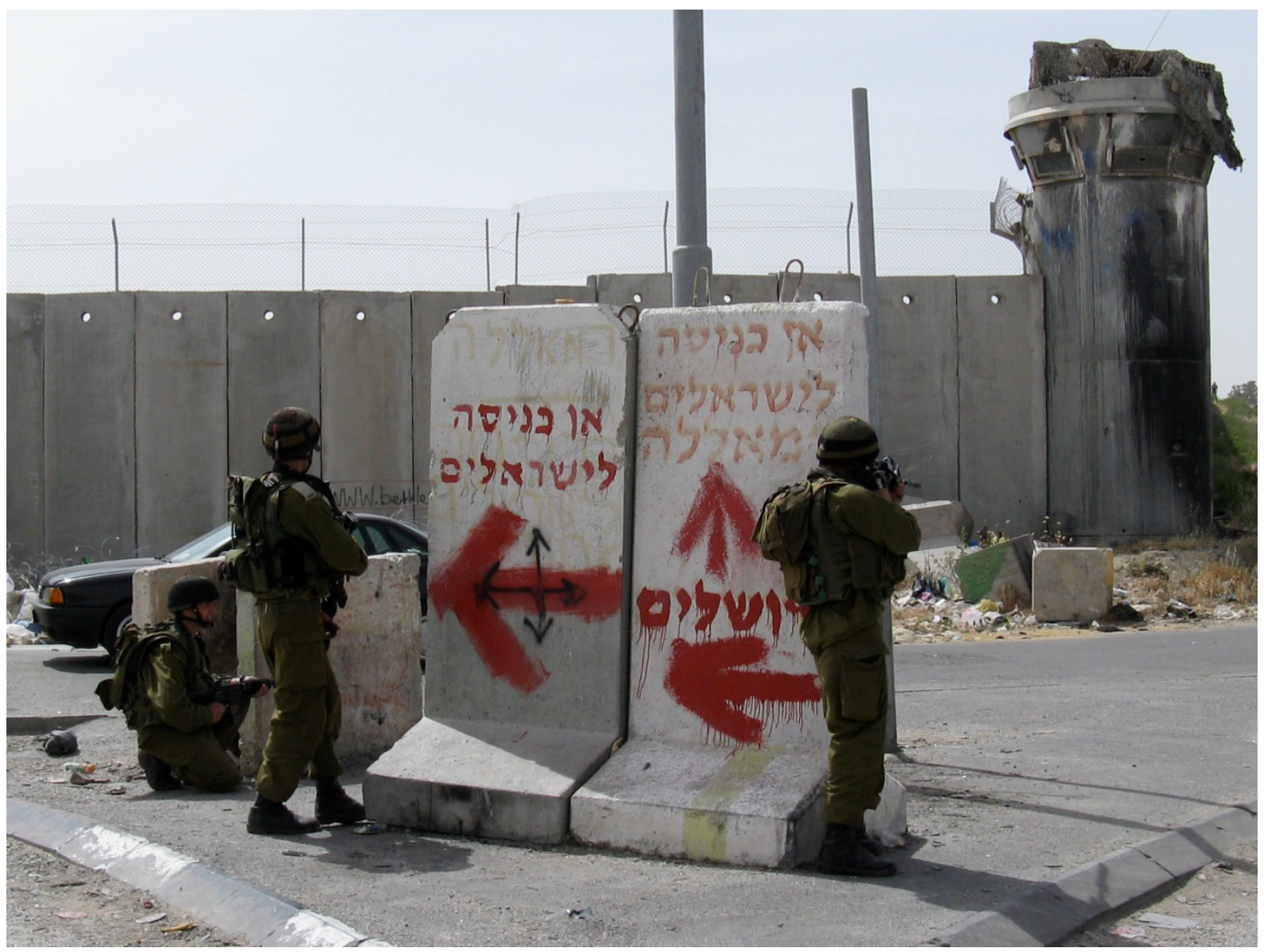

Figure 11. Kalandia Checkpoint, Palestine May 2008.

Photo: Annie Pfingst

As colonial emergencies map and patrol territory, control and punishment, containment and closure is effected through militarised violence, the form and intensity of which is enabled and authorised through racialised hierarchies. Racial vocabularies frame acts of defiance, disloyalty and rebellion. In both the emergency in Kenya and the administration of a state of emergency over Palestine, military defence authorises practices of curfew and siege, of surveillance and monitoring, of aerial bombing and of execution. In the Occupied Palestinian West Bank and East Jerusalem, the regulations of the state of emergency have been taken into the military orders of belligerent occupation. In the political and military actions against the forces of resistance, colonial emergency military control designated both the Mau Mau movement and the Hamas movement as terrorist organisations, rendering them legitimate military targets. Palestinians are regularly arrested, most often as administrative detainees, for belonging to organisations proscribed under the provisions of emergency regulations.

Precision attacks on Palestinian resistance leaders and operatives are carried out either as targeted assassinations or as part of military operations. Mau Mau attempts to propel the end of colonial control were regarded as terrorist activity and the punishment of the forest fighters 
went beyond detention. In an attempt to flush the gangs out of both Mt Kenya and the Aberdares in the Central Highlands, British forces bombed the forest locations and the caves of the forest fighters. The remnants and sites of some of the gallows used to hang Mau Mau adherents and mass graves from the emergency can be found across the post-independence Kenyan geography. The location of Emergency screening centres, detention and works camps - Hola, Manyani, Aguthi, Athi River, Mackinnon Road, Mwea, Kamiti, Lamu - rendered the wide Kenyan landscape, from the Central Highlands to the northern frontier, from the western exile islands on Lake Victoria to the detention prisons on the eastern islands of Lamu and Mombasa of the Emergency era militarised zones.

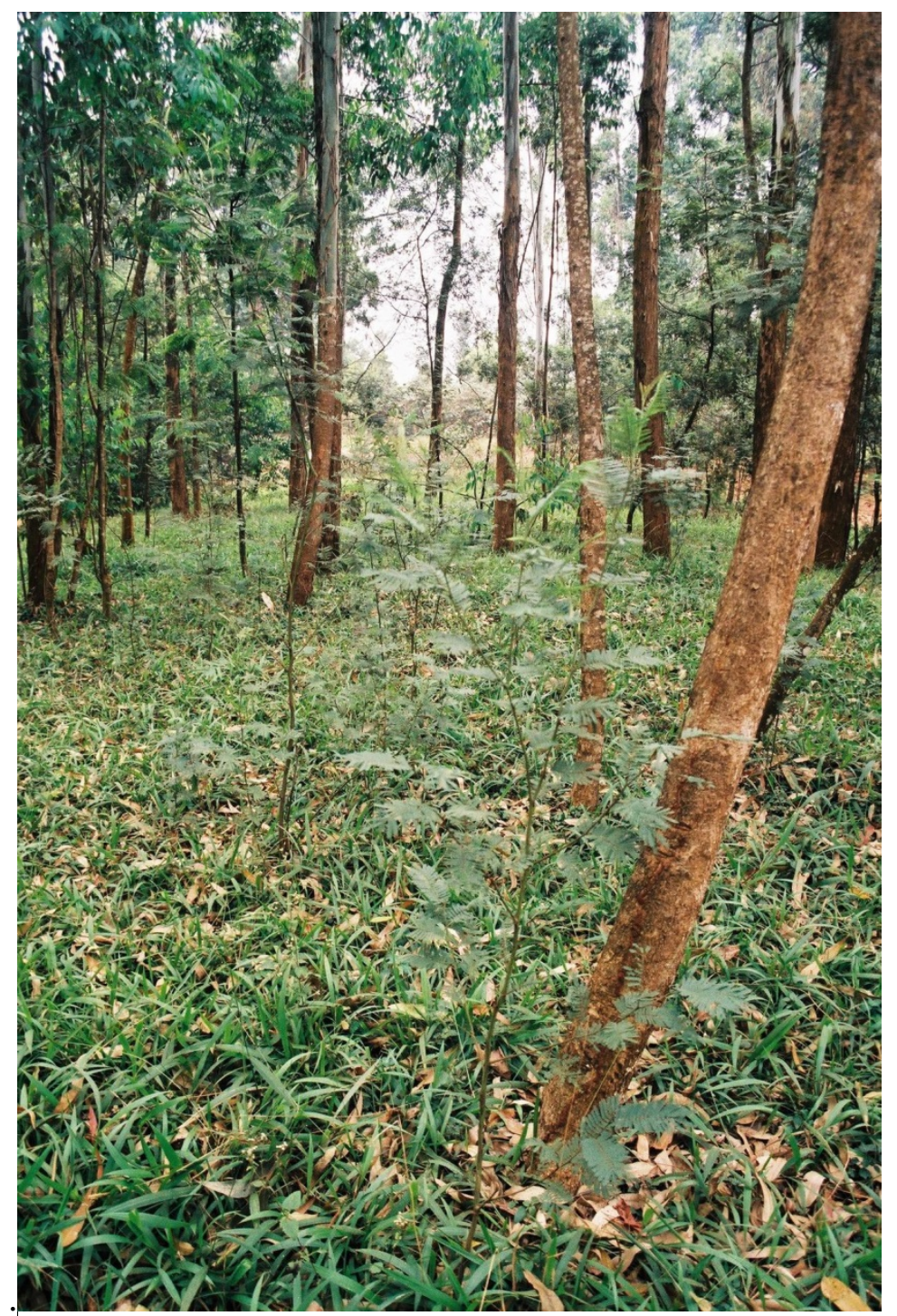

Figure 12. Gikondi, Nyeri district, site of mass grave, Kenya 2013. Photo: Annie Pfingst

The prisons that detain Palestinian administrative detainees are similarly scattered across the landscape. Together with the areas designated as closed military and firing zones inside 
the '48 state, and the settlements and outposts on hilltops, the checkpoints, the fences, the barriers and the Wall, surveillance towers, and the separate roads and bridges in the occupied Palestinian territories, assemble the constantly composed and recomposed militarised landscapes across historic Palestine.

The southern Naqab/Negev is effectively a series of connected military zones. Across and between the deep valleys and rugged hills of the Naqab south to the Egyptian border, west to the zones along Gaza, and east and north to the Judean Hills all the land, as far as the horizon and through all the wadis, is designated military; square concrete blocks sit along the roads at every possible path or dirt road declaring the land as dangerous, closed, a firing range; Ketzion, Nafah and Ramon prisons in which Palestinian detainees are held; military bases on hill tops; the buildings of Holot the open detention camp for asylum seekers; the white circular domes of surveillance installations; the miles of perimeter fences that enclose airforce bases and deep in the hills, secret military bases, known but hidden. This was once the land of the Bedouin before the expulsions of 1948 when the area was designated for military use. It is said that 5,000 Bedouin were expelled to make way for the construction of the Nevatim air base in the 1980s (Human Rights Watch 2008). Now there are plans to bring 10,000 IDF to what is being described as a city of bases under construction south of Beer Sheva. Up and down throughout the Jordan Valley, a third of the occupied West Bank, Bedouin villages lie in ruins after demolition for illegal construction, demolished to make way for the expansion and development of settlements illegal under international law, located in Area C under the Oslo Agreement over which Israel holds security control.

Civilian and military zones of settlement and occupation are further mapped onto the geographies of resistance. The resulting landscapes become layered by remnants - of the sites and locations of detention, of interrogation and torture, of enforced labour, of military violence, of resistance and anti-colonialism, of landscapes lost under sites of settlement and of military constructions and closures. Tucked in between buildings and the pathways of a school in Mweru, Nyeri County, Kenya, sits a tiny brick and mapati building, securely locked and with one tiny opening high up on one wall letting the only light into what was otherwise a dark restricted space that, according to the panel on the front, tells us that this was used for the torture of Mau Mau. Found across the landscapes of Kenya, these remnants of the structures for detention, for example at Othaya Approved School, or even the absence of their presence, as in the site of the former Langata Screening camp now the Uhuru Gardens 
Memorial Park, or the structures built through the works camps and the forced labour of those detained - including the Githunguri stadium and the one at Rurig'u - can also be apprehended as the 'spasmodic irruptions of multiple pasts into the condensed present' (Benjamin in Gregory 2004, p. 7). The goal post on the field within the Rurig'u stadium is the site at which the forest fighters laid down their arms on independence. Nearby is the Mau Mau Flag Site - erected in memory of freedom fighters 1951-57 - where the promise to fight for independence was made.

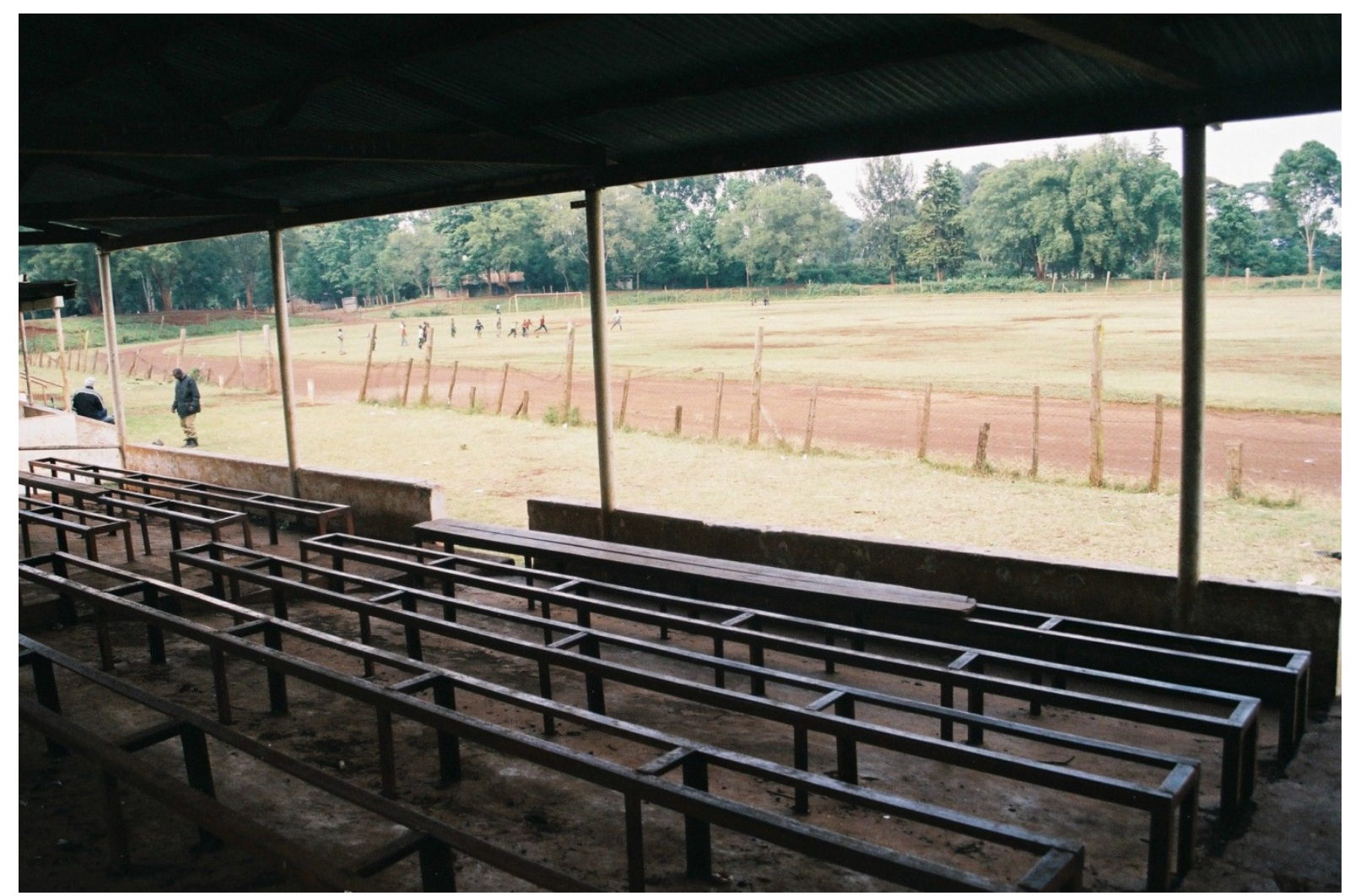

Figure 13 Rurig’u Stadium, Nyeri, Kenya 2013.

Photo: Annie Pfingst

I walked with my guides along a path deep in the Kenyan landscape down a steep gully, past waterfalls, through rock formations and dense forest and across rocks, to the Kariba Mau Mau shelter located just above and beside the fast flowing Ruiri River at Ngaine, in Nyeri District. A place for quiet contemplation and prayer, the roof of the small cave is black from the cooking fires of Mau Mau sheltering here during the period of the Emergency; down another steep path, it's entrance hidden by a waterfall, to the Mau Mau cave on the Kahuru River, Thigingi sub/location in Nyeri District. 


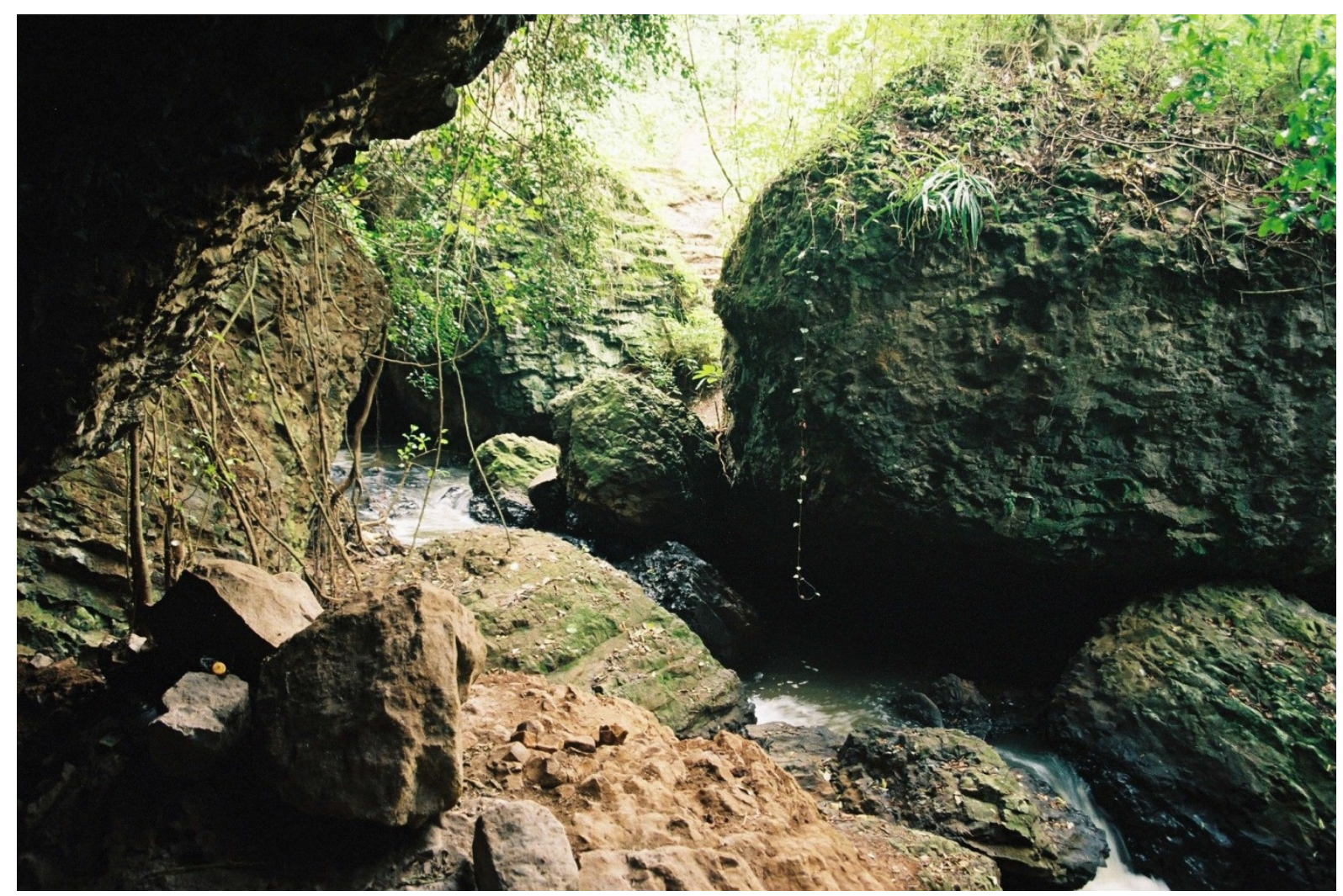

Figure 14. Ruiri River, Ngaine, Nyeri District, Kenya 2013.

Photo: Annie Pfingst

Some way into the Mount Kenya forest, once more deep in a gully, I walked through the landscape of waterfalls, pools, forest and cave shelters that is the location of the Burguret Mau Mau shelter at Gakawa, part of a network of caves and shelters, hideouts and forest paths that made up the Mau Mau geography. The Mau Mau cave at Naromoru, perhaps one of the largest, with a wide mouth hidden by vegetation, stretches far into the hillside. In the imagination of the colonial emergency administration, the forest fighters were the penultimate enemy, terrorists engaged in a guerrilla war. Much of the British colonial policy throughout this time was aimed at reducing the capacity of the forest fighters to continue. Inducements were offered to surrender; leaflets calling for surrender were dropped over the forests; rewards were offered for information or the capture of forest fighters; and pseudo gangs were organised to find the fighters in the forests and to arrange their capture or surrender. British fighter planes dropped bombs over the forest targeting what they believed to be Mau Mau hideouts. 


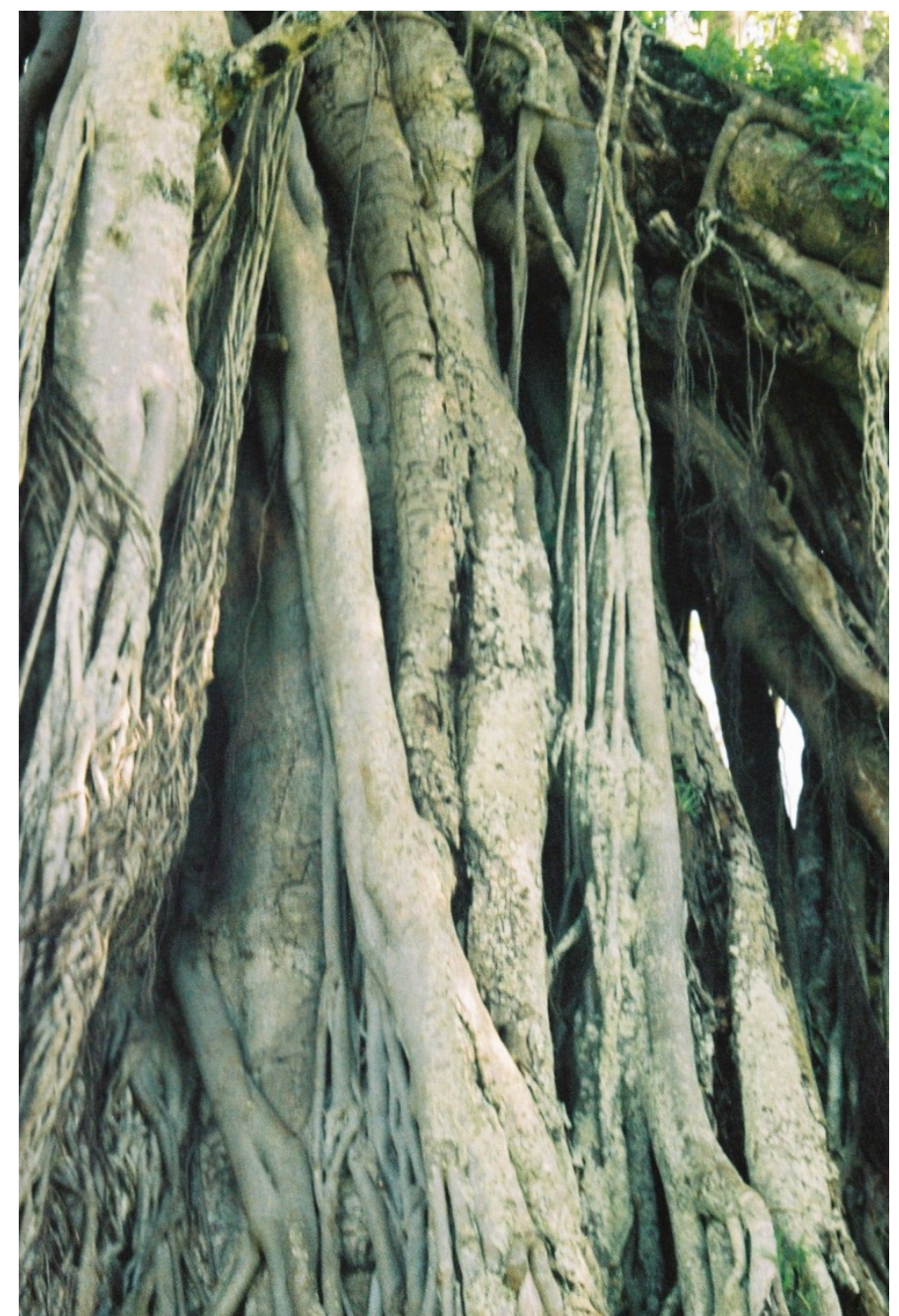

Figure 15. Mau Mau post-office, Aberdare National Park, Kenya 2013 Photo: Annie Pfingst

These spatial, temporal and material encounters across the multiple sites and locations of Mau Mau resistance and the remnant architectures and technologies of colonial violence and control occur at the intersections of colonial and post-independence geographies - from Eastleigh to the forests, from detention camps to the pipeline, from passes and IDs to the concentrated villages, from forced labour to the rehabilitation programs in the forest villages, from wire fences to spiked trenches, from the central region to the northern frontier, from the coastal centres to the exile islands. The movement to end colonialism mapped itself through and onto multiple connected geographies. 


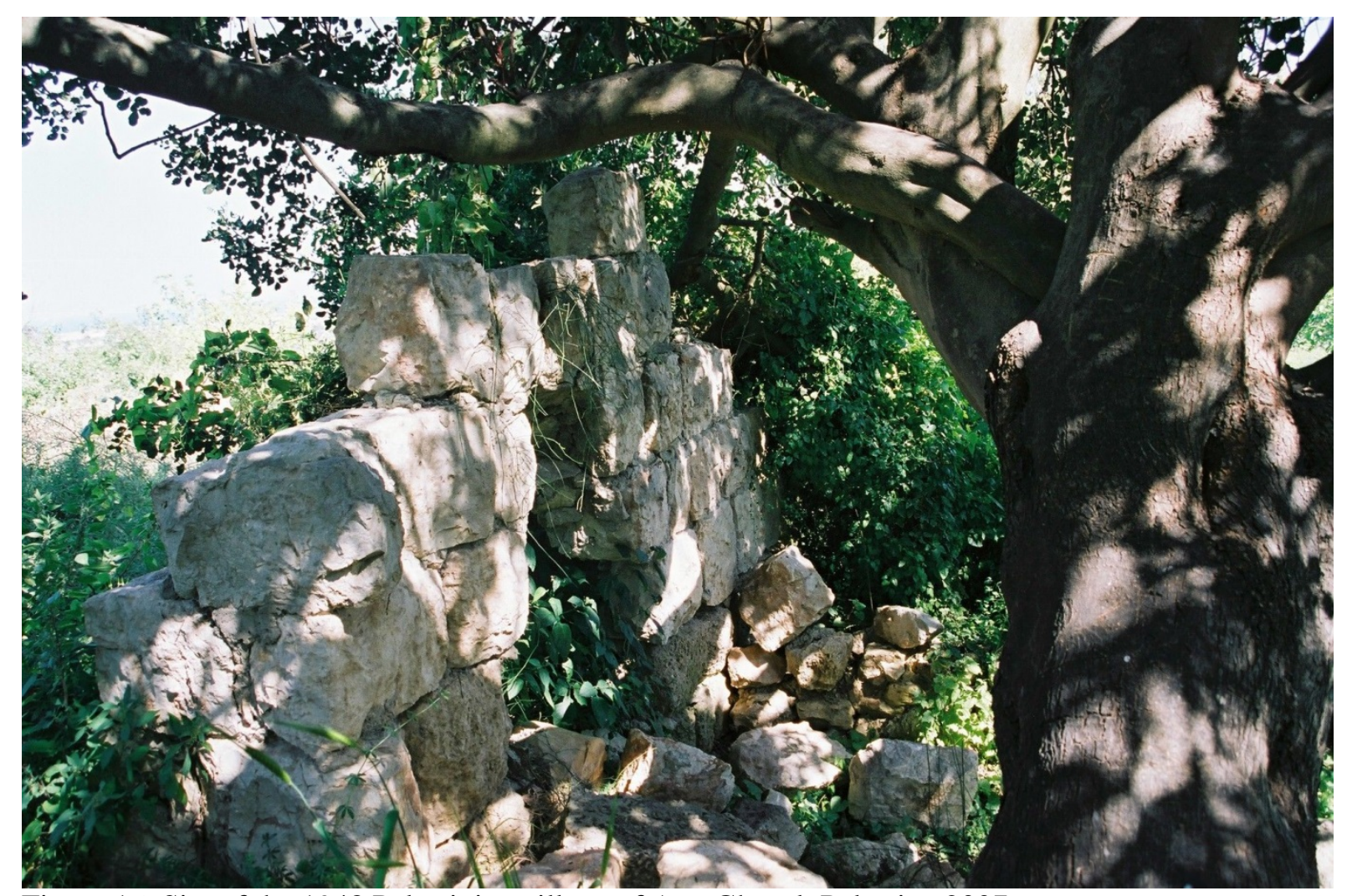

Figure 16. Site of the 1948 Palestinian village of Ayn Ghazal, Palestine 2007. Photo: Annie Pfingst

The remnants of Palestinian villages, scattered across the 1948 state landscape, can be found under the Jewish National Fund (JNF) forests or incorporated into kibbutzim. The 1967 Palestinian West Bank and East Jerusalem are overlaid by the architectures and spatial arrangements of settlement and military control. State-imposed emergency authorises the continuing erasure and enclosure of Palestinian space and life and maps itself onto Palestinian geographies of resistance both inside the ' 48 state and in the Occupied Palestinian Territories.

In Al Jalazone refugee camp outside Ramallah, building goes up, a vertical stack of apartments, so that the original small concrete shelters from the 1950s are hidden, barely visible, some disused, others disappeared into the vertical structures that have overtaken them; in Aqabat Jaber refugee camp in Jericho infrastructure for water and waste is implemented in order to enable a passable life without ever forgetting that life continues as the life of refugees. The UN distributes food, now no longer to all refugees, but to those in hardship, disabled, old. In Iftliq, the Bedouin rebuild their houses and communal structures after the everyday occurrence of demolition. Their poverty and precarity palpable as they live 
crammed up against the rocky hills in Israeli controlled Area C of the Occupied Jordan Valley.

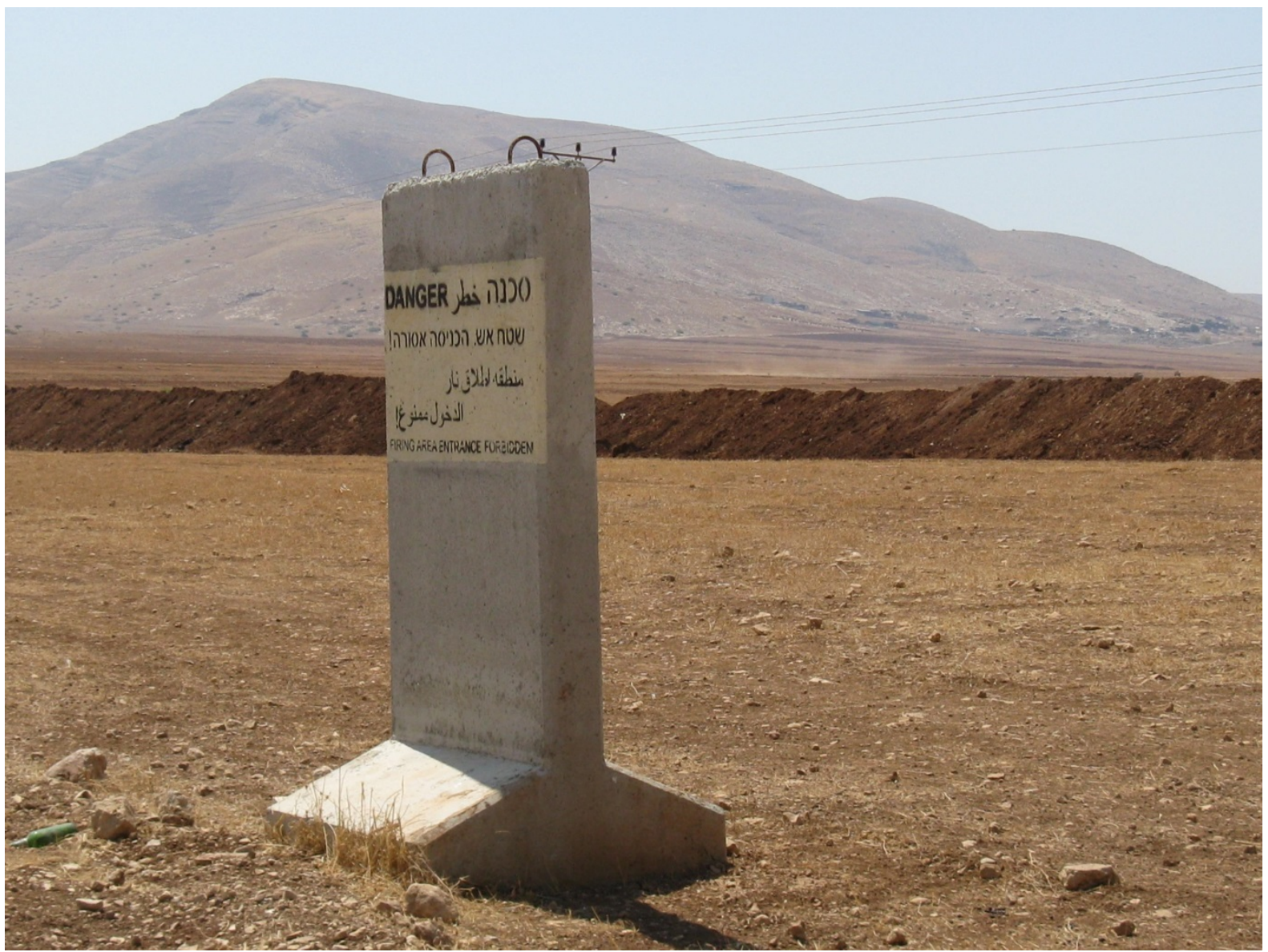

Figure 17. Jordan Valley, Palestine.

Photo: Annie Pfingst

Israeli liability for the deaths of civilians throughout the military offensive against Gaza in July-August 2014 is framed by the abrogation of internationally recognised norms of humanitarian law, of the laws of war and of the obligation of the occupying entity to protect the lives of those under occupation. Palestinians can only sift through the debris of destruction on an already devastated and fragmented landscape. If for Israel this constitutes the 'completion of the war of independence', of 1948, for Palestinians it is the continuation of al Nakba authorised under the conditions of a colonial declared emergency as the state attempts to effect 'calm' - the end of disorder, the end to resistance. ${ }^{14}$

\footnotetext{
${ }^{14}$ As the 2014 'Operation Protective Shield' ground offensive on Gaza was prepared, the Israeli daily, Ha'aretz, reported that arrests during demonstrations in Jerusalem and in the Negev (Naqab) had been made 'on suspicion of involvement in disruptions of order' (Ha'aretz July 8.2014); that 'violence and disruption of order' would be dealt 'with a hard hand' (Ha'aretz July 5 2014) echoing the language of Emergency Regulations.
} 


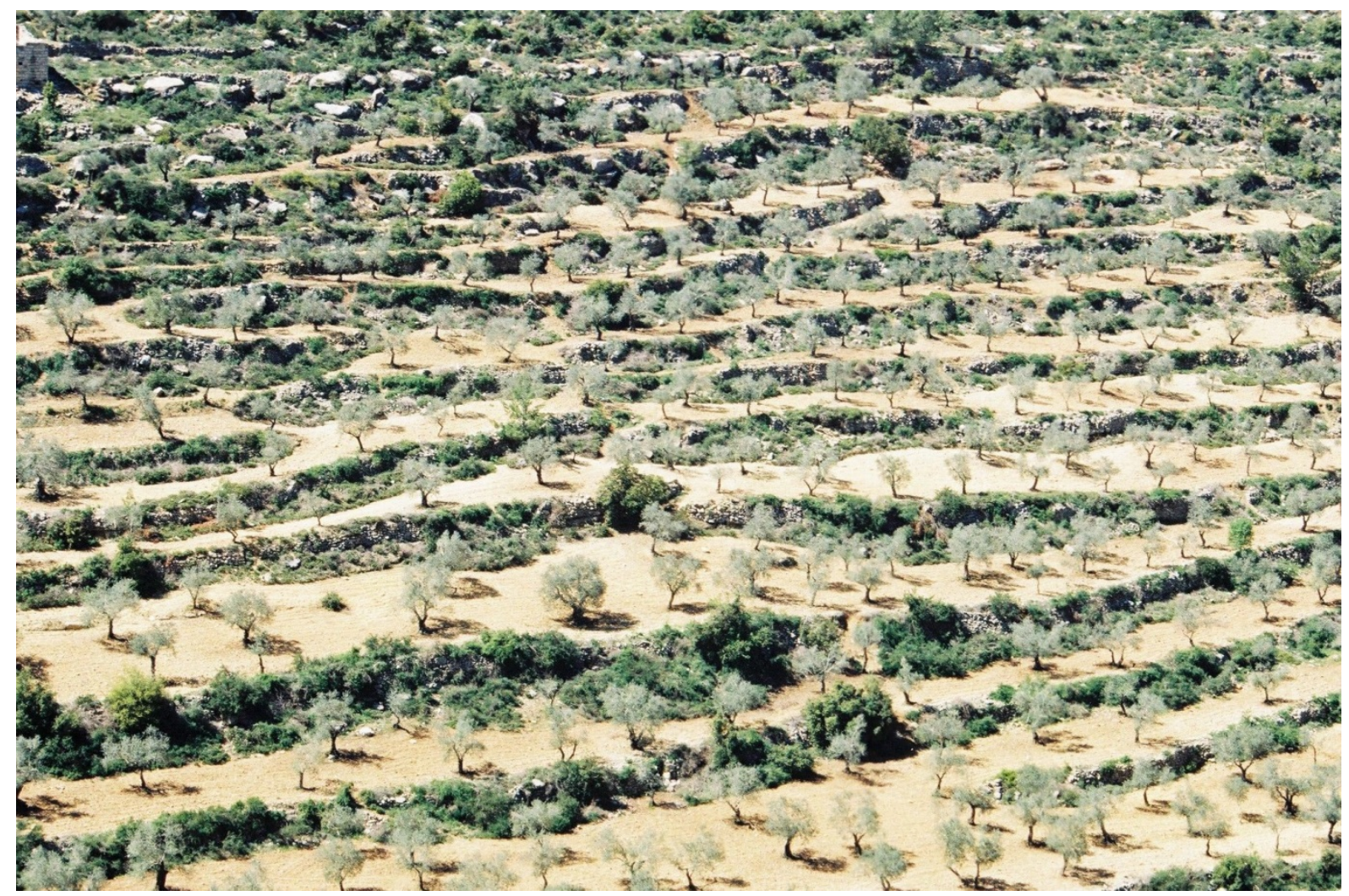

Figure 18. Ramallah Hills, Palestine 2014.

Photo: Annie Pfingst

\section{Acknowledgements}

The research for Emergency: a genealogy of emergency regulations was supported by a

British Academy/Leverhulme Trust small research grant.

This essay extends 'Emergency geographies and archives of militarised violence - Palestine and Kenya' first presented to WHOSE 'EMERGENCY'? Interrogating 'emergencies': Australia, Kenya, Palestine, Congo, India, Malaysia, May 2014, University of Technology, Sydney.

\section{References}

Ali Abunimah 07/07/2014, 'Israeli lawmaker's call for genocide of Palestinians gets thousands of Facebook likes’, Electronic Intifada, accessed 11 August 2014, http://electronicintifada.net/blogs/ali-abunimah/israeli-lawmakers-call-genocidepalestinians-gets-thousands-facebook-likes

Anderson, David, 2005, Histories of the Hanged: Britain's Dirty War in Kenya and the End of Empire, Phoenix, London. 
Association for Civil Rights in Israel (ACRI), 2012, Supreme Court Rejects Petition to End Continual State of Emergency, ACRI, accessed 2 March 2014 www.acri.org.il/en/2012/05/08/state-of-emergency-petition-rejected/

Azoulay, A. 2008, The Civil Contract of Photography, Zone Books, New York.

Azoulay, A. 2012, Civil Imagination: a political ontology of photography, Verso, London.

Azoulay, A. and Ophir, A. 2012, 'Abandoning Gaza' in Svirsky, M. and Bignall, S. (eds.), Agamben and Colonialism, Edinburgh University Press, Edinburgh.

Moffett, M. 1989, Perpetual Emergency: an analysis of Israel's use of the British Defence (Emergency) Regulations, 1945, in the Occupied Territories, al Haq, Ramallah.

Adv. Ben-Natan, Smadar, Adv. Atamleh-Mohana, Tahrees, Adv. Wolf Goldstein, Lymor (eds), 2009, 'The Defence (Emergency) Regulations, 1945' in The Law of the Israeli Military Courts in the West Bank: Military Orders and Israeli Domestic Legislation Source Book, MachsomWatch, Public Committee against Torture in Israel and Palestinian Prisoner Society.

B'Tselem -The Israeli Information Center for Human Rights in the Occupied Territories, Deportation, accessed 12 August 2014, http://www.btselem.org/topic/deportation

Butler, J. 2004, Precarious Life, Verso, London.

Butler, J. 2009, The Frames of War: When is Life Grievable?, Verso, London.

Elkins, C. 2005 a, Britain's Gulag: the Brutal End of Empire in Kenya, Pimlico, London.

Elkins, C. 2005 b, 'Race, Citizenship, and Governance: Settler Tyranny and the End of Empire' in Elkins, C. and Pederson, S. (eds.), Settler colonialism in the Twentieth Century: policies, practices, legacies, Routledge, London.

Elkins, C. and Pederson, S. (eds.), 2005, Settler colonialism in the Twentieth Century: policies, practices, legacies, Routledge, London.

Farred, G. 2008, 'The Unsettler', South Atlantic Quarterly, vol.107, no. 4, pp. 791-808. http://dx.doi.org/10.1215/00382876-2008-017

Government of the UK, Statement to Parliament on settlement of Mau Mau claims, accessed 30 April 2014, https://www.gov.uk/government/news/statement-to-parliament-onsettlement-of-mau-mau-claims

Gregory, D. 2004, The Colonial Present: Afghanistan, Palestine, Iraq, Blackwell, Oxford.

Guha, R. 1988, 'The Prose of Counterinsurgency' in Guha, R. and Spivak, C. (eds.), Selected Subaltern Studies, Oxford University Press, Oxford, pp. 45-84.

Ha'aretz 5 July 2014, Live updates, July 5: Riots grip E. Jerusalem, Arab towns, accessed 11 August 2014 http://www.haaretz.com/news/diplomacy-defense/1.603150

Ha'aretz, 8 July 2014, Netanyahu orders IDF to prepare for Gaza ground offensive; IAF strikes 50 targets in Gaza Strip as rocket fire on Israel's south continues, http://www.haaretz.com/news/diplomacy-defense/1.603677

Hamilton, C. et al. (eds.), 2002, Refiguring the Archive, Kluwer Academic Publishers, Dordrecht. http://dx.doi.org/10.1007/978-94-010-0570-8

Hamoked, 2002, Incarceration of Unlawful Combatants Law, 5762-2002, Legislation 4.3.2002, http://www.hamoked.org/Document.aspx?dID $=240$

Human Rights Watch, 2008, Off the Map: Land and Housing Rights Violations in Israel's Unrecognised Bedouin Villages, Human Rights Watch, New York.

Israeli Campaign Against House Demolitions (ICAHD), Get the Facts, accessed 11 August 2014, http://www.icahd.org/the-facts

Israeli Provisional Council of State 1948. Law and Administration Ordinance No. 1 of 57081948, published 19 May 1948, accessed 14 July 2014, http://www.geocities.com/savepalestinenow/israellaws/fulltext/lawandadministrationor $\underline{\text { d.htm }}$ 
Khalili, L. 2013, Time in the Shadows: Confinement in Counterinsurgencies, Stanford University Press, Stanford.

Kohn, M. and McBride, K. 2011, Political Theories of Decolonization: Postcolonialism and the Problem of Foundation, University of Oxford Press, New York. http://dx.doi.org/10.1093/acprof:oso/9780195399578.001.0001

Lesch, A. 1979, 'Israeli Deportation of Palestinians from the West Bank and the Gaza Strip, 1967-1978', Journal of Palestine Studies, vol. 8, Winter.

Mahozay, Y. 2012, 'The Fluid Jurisprudence of Israel's Emergency Powers: Legal Patchwork as a Governing Norm', Law \& Society Review, vol. 46, no.1, pp. 137-166. http://dx.doi.org/10.1111/j.1540-5893.2012.00475.x

Mbembe, A. 2001, On the Postcolony, University of California Press, Berkeley.

Mbembe, A. 2002, 'The Power of the Archive and its Limits' in Hamilton, C. et al. (eds.), Refiguring the Archive, Kluwer Academic Publishers, Dordrecht, pp. 19-27. http://dx.doi.org/10.1007/978-94-010-0570-8_2

Mbembe, A. 2003, 'Necropolitics', Public Culture vol. 15, no. 1, pp. 11- 40. http://dx.doi.org/10.1215/08992363-15-1-11

Mondoweiss, May 20, 2014, New video shows Palestinian youths killed by Israeli army on Nakba Day posed no threat to soldier, accessed 4 August 2014, http://mondoweiss.net/2014/05/palestinian-israeli-soldiers.html

Morton, S. 2012, 'Reading Kenya's Colonial State of Emergency after Agamben' in Svirsky, M. and Bignall, S. (eds.), 2012, Agamben and Colonialism, Edinburgh University Press, Edinburgh.

Morton,S. 2014, States of Emergency: Colonialism, Literature and Law, Liverpool University Press, Liverpool.

Ophir, A. 2009, 'The Politics of Catastrophization', Roundtable: Research Architecture: Centre for Research Architecture, Goldsmiths College, University of London, http://www. roundtable, kein.org/node/1094

Pappe, I. 2008, 'The Mukhabarat State of Israel: a state of oppression is not a state of exception’ in Lentin, R. (ed.) Thinking Palestine, Zed Books, London, pp. 148-169.

Pfingst, A. and Rosengarten, M. 2012, 'Medicine as a tactic of war' in Body and Society, vol.18, no 3/4, pp. 99-125. http://dx.doi.org/10.1177/1357034X12446381

Reynolds, J. 2013, 'Intent to regularize: The Israeli Supreme Court and the Normalisation of Emergency’, Adalah's Newsletter, vol.104, May 2013, http://adalah.org/eng/Articles/2127/“Intent-to-regularise":-The-Israeli-Supreme

Segev, T. 2000, One Palestine, Complete: Jews and Arabs under the British Mandate, Abacus, London.

Stengers, I. 2005, 'The Cosmopolitan Proposal' in Latour, B. and Weibel, P. Making Things Public: Atmospheres of Democracy, MIT Press, Cambridge, MA, pp. 994-1003.

Stoler, A. 2002, 'Colonial Archives and the Arts of Governance: On the Content in the Form' in Hamilton, C. et al. (eds.), Refiguring the Archive, Dordretch, Kluwer Academic Publishers, Dordrecht, pp. 83-102, http://dx.doi.org/10.1007/978-94-010-0570-8_7

Svirsky, M. and Bignall, S. (eds), 2012, Agamben and Colonialism, Edinburgh University Press, Edinburgh.

Tawil-Souri, H. 2011, 'Colored Identity: the politics and materiality of ID cards in Palestine/Israel', Social Text 107, vol.29, no.2.

United Nations Office of the Coordination of Humanitarian Affairs in the Occupied Palestinian Territories (UNOCHA oPt), Occupied Palestinian Territory: Gaza Emergency, Situation Report, 12 August 2014, accessed 12 August 2014, http://www.ochaopt.org/documents/ocha_opt_sitrep_12_08_2014.pdf 
Wolfe, P. 1999, Writing past colonialism - Settler colonialism and the transformation of anthropology - the politics and poetics of an ethnographic event, Cassell, London.

Wolfe, P. 2006, 'Settler colonialism and the elimination of the native', Journal of Genocide Research, vol. 8, no. 4, pp.387- 409. http://dx.doi.org/10.1080/14623520601056240

Wolfe, P. 2008, 'Structure and Event: Settler Colonialism, Time, and the Question of Genocide' in Moses, A.D.(ed.) Empire, Colony, Genocide : Conquest, Occupation, and Subaltern Resistance in World History, Berghahn Books, New York, pp.102 - 132.

The National Archives Kew (TNA): (in order of appearance in text)

CO/822/443 - Original correspondence; Proclamation of a State of Emergency in Kenya. Governor Baring to Secretary of State, October 1952.

FCO 141/6809 - Confiscations of Land. Note on Amendment to the Forfeiture of Land Ordinance, Minister of African Affairs, 27 June 1956.

FCO141/6145, 1954 - Mau Mau unrest; corporal punishment. Corporal Punishment, Memorandum on Whipping, under cover letter Executive Officer, Nairobi- Extra Provincial District Emergency Committee to Deputy Secretary (civil) Cabinet Office, 12 August 1954.

Kenya Weekly 31 July 1959 in FCO141/5655 Mau Mau Unrest; death of eleven detainees at Hola Detention Camp, 3 March 1959.

FCO 141/6521, 1954-58, Screening camps: Mau Mau Investigation Centre, Embakasi. Inquiry into Screening Camps and Interrogation Centres under the Control of the Provincial Administration, p.2.

FCO141/6750, 1953, District Officer, Londiani Forest Division: correspondence on Home Guards and Screening. Office of the Provincial Commissioner, Rift Valley Province to Employers of Kikuyu Labour, Rift Valley Province, 4 January, 1954

CAB.129/65- Detention of Supporters of Mau Mau. Telegram No 72, 27 January 1954 from the Governor of Kenya to the Secretary of State for the Colonies. Annex to Memorandum by the Secretary of State for the Colonies, 8 February 1954.

FCO141/6298 - Detainees and Detention Camps. Mr Hare Reply to Barbara Castle, 22 February 1956.

FCO141/6298 - Detainees and Detention Camps. Telegram from the District Commissioner's Office Embu to the Special Commissioner, Nyeri, Screening of Detainees at Manyani, 27 August 1956.

FCO 141/6521, 1954-58, Screening camps: Mau Mau Investigation Centre, Embakasi. Inquiry into Screening Camps and Interrogation Centres under the Control of the Provincial Administration, p.3.

FCO822/728 Press Office Handout No 139 - New Emergency Regulations, Press Office, Nairobi, 18 May 1953.

CO822/451 Activities of the Advisory Committee on detainees established under the Emergency Regulations Kenya 1952-53.

C0822/801 1956 Detention camps set up for emergency in Kenya, 1 January 1954 - 31 December 1956.

Kenya National Archives and Documentation Centre, Nairobi: (KNA):

OP/E/1/982 - Unrest - Villagisation 1954-59, En Clair Telegram from the Governor to the Secretary of State, 21 February 1955. 